Bull. Fac. Agric., Cairo Univ., 68:251- 268. (2017).

\title{
RESPONSE OF SPEARMINT (Mentha viridis L.) AND GERANIUM (Pelargonium graveolens $l$ herit, ait) PLANTS TO DIFFERENT WEED CONTROL PRACTICES
}

(Received: 28.11.2017)

\author{
By \\ A.M. Fadlallah , S.M.M. Salem * and I.E. Soliman

\begin{abstract}
Weed Research central laboratory, and * Horticulture Research Institute,
\end{abstract} \\ Agriculture Research Center, Giza, Egypt
}

\begin{abstract}
Four field experiments were conducted at the experimental farm of Medicinal and Aromatic Plants Research Department, El-kanater El-khairia Qalubia Governorate and Horticulture Res. Institute, Agric., Res., Center, Giza, Egypt, during two successive seasons (2014-2015 and 2015-2016) including two studies on controlling weeds in spearmint and geranium plants. The objective of this work was to determine the efficacy of some weed control treatments (herbicides and physical methods) on weed control and yield productivity and quality of spearmint (Mentha viridis L.) and geranium (Pelargonium graveolens L. Herit Ait.) plants. The first study aimed to determine the effect of six weed control treatments (Anmex, $2.5 \mathrm{~L} / \mathrm{fed}$. stomp, $1.7 \mathrm{~L} / \mathrm{Fed}$. Roal, $750 \mathrm{~cm}^{3} / \mathrm{Fed}$. ,Select super, $0.5 \mathrm{~L} / \mathrm{Fed}$., hand hoeing and control treatment (untrested) on weeds and spearmint yield's components (herb fresh and oil).

The results showed that the density of broad weeds in the standard treatment was estimated as $0.97 \& 0.45 \mathrm{Ton} / \mathrm{Fed}$. while the annual density of weeds was $0.43 \& 0.24 \mathrm{Ton} / \mathrm{Fed}$. in the two seasons of 2014 \& 2015 respectively, the best treatments for weed control were under the conditions of the experiment, the Stomp extra with a rate of $1.7 \mathrm{~L} / \mathrm{Fed}$. where the least dry weight was given to broad grass and narrow leaves, all with an increase in vegetative growth (plant high - number of branchesfresh weight and the oil yield of spearmint plant), also the treatment resulted from a Roal of 750 $\mathrm{cm}^{3} /$ Fed. gave the highest percentage in the compound Carvone in spearmint oil . In the second study six weed control treatments were conducted in the Geranium yield : Stomp extra with a rate $1.7 \mathrm{~L} / \mathrm{Fed}$. , Roal at $750 \mathrm{~cm}^{3} / \mathrm{Fed}$. and Select super at $0.5 \mathrm{~L} / \mathrm{Fed}$. coverage with black plastic, three times hand hoeing and control treatment (untreated treatment) to study their effected on weeds and vegetative growth (plant height - number of branches - fresh weight and percentage of volatile oil components) .The results indicted that the density of broad weeds in the standard treatment was estimated at 0.75 \& $0.70 \mathrm{Ton} / \mathrm{Fed}$., while the annual density of weeds was $0.43 \& 0.3 \mathrm{Ton} / \mathrm{Fed}$. for the two seasons $2014 / 2015$ and 2015/2016 respectively and the addition of Stomp extra by $1.7 \mathrm{~L} / \mathrm{Fed}$. casued reduction in the dry weight of the annual grass and the highest values in the vegetative growth and oil yield, while the treatment with a Roal of $750 \mathrm{~cm} 3 / \mathrm{Fed}$. was the highest percentage in the compound Geraniol the main compound of the oil of Geranium. By analyzing the Spearmint and Geranium plants there was no residual effect of herbicides under the two studies. The economic analysis indicated that the economic feasibility of these treatments in terms of expected returns and farmers revenue by the Egyptian pounds.From the results it could be concluded that by using Stomp extra at $1.7 \mathrm{~L} / \mathrm{Fed}$. in controlling the annual weeds in Spearmint and Geranium plants, it gave the highest value in oil yield and vegetative growth and no residues were detected in fresh herbs of Spearmint and Geranium and also mulching with black plastic sheets as a natural substitutes for weed control instead of the herbicides.
\end{abstract}

Key words: Controlling weeds,(Spearmint \& Geranium) plants, herbicides, residual.

\section{INTRODUCTION}

Spearmint and geranium are considered as two of the most important medicinal and aromatic plants grown in Egypt for local consumption processing and exportation. In
2015, the cultivated area of spearmint and geranium reached 6448 and 4880 faddans producing an average of 20.63 and 21.37 ton of herbs/faddan, respectively (Egyptian Ministry of 
Agric, 2015). The demand and production for medicinal plants as natural products and recombinant proteins for medicinal purpose have substantially increased in the world market over the last decades. (Anonymous, 2012). These herbal plants are very weak competitors to weeds and there is a need to control these weeds by physical or mechanical methods to be free of herbicides residues. Among selective herbicides that can be used in these two crops are oxyfluorfen as pre-emergence (pre-em) herbicide. It gives very good weed control and when followed later in the season by sethoxydim or fluazifop-butyl also gives excellent weed control up to harvest. Meanwhile oxyfluorfen when applied as emergence, it causes phytotoxicty and becomes more so when applied as post-em. In spearmint, oxyfluorfen at $1 \mathrm{lb}$ a.i./acre, applied during the dormant period, was well tolerated during the growing seasons (Romanowski et al., 1980). Pendimethalin at 4.0 1/ha, metolachlor at $1.01 /$ ha and oxadiargyl at $0.5 \mathrm{~kg} / \mathrm{ha}$ effectively controlled the weeds with no adverse effect on the raspberry plants (Rankova and Koumanov, 2004). The use of natural method by soil mulching as application of paddy straw mulch increased the herb and essential oil yields in geranium by $23 \%$ and $27 \%$ respectively, over the unmulched control at planted crops harvest (Muni and Roy,2003). Unrestricted weed growth significantly reduced geranium oil yield, by 61.6 and $70.6 \%$ in 1999 and 2000, respectively. Pre-emergence application of pendimethalin $(0.75-1.00 \mathrm{~kg} / \mathrm{ha})$ or oxyfluorfen $(0.25 \mathrm{~kg} / \mathrm{ha})$, successive handweeding, hoeing, and mulching and three handweeding were highly effective in reducing weed density and dry weight and gave oil yield comparable to the weed-free check. Application of oxyfluorfen $(0.15$ or $0.20 \mathrm{~kg} / \mathrm{ha})$ and pendimethalin $(0.50 \mathrm{~kg} / \mathrm{ha})$ were less effective in controlling the weed species in geranium (Kothari et al., 2002). Mulch removal in May and July led to a significant increase of summer annual weeds, especially Cyperus $s p$. and lindernia sp (Mineta et al., 1997). Successful control of weeds with terbacil when used as a pre-emergence herbicide in Japanese mint. Wallia et al., (1980) and Katoch et al., 1982 observed that terbacil at $1.5 \mathrm{~kg}$ product/ha preemergence, effectively controlled both the dicot and monocot weeds in the first harvest, but thereafter weeding at 40 days intervals was most effective for yield and herb oil. Bernsier and Gallotte, (1989) reported that terbacil and bentazon are registered for pre-emergent and post-emergent use, respectively, on both Peppermint and spearmint in the USA.(El-Masry et al., (1989) reported no change in oil composition after the post-emergence application of bentazon and graminol. On the other hand, literature on weed control in medicinal plants is found very scarcely. Currently, there are no recommended herbicides nor alternative physical methods to overcome the common weeds associated with spearmint and geranium. Thus the aim of the present study was to evaluate some promising herbicides and physical methods for controling weeds and to increase the quality and quantity of these medicinal and aromatic plants.

\section{MATERIALS AND METHODS}

Four field experiments were carried out in clay soil at the experimental farm of Medicinal and Aromatic Plants Research Department, Horticulture Research Institute, Agriculture Research Center, El-Kanater El-Khiria, Qalubia Governorate, Egypt during the period from 2014 to 2016 seasons. The objective of the study was to evaluate weed control treatments on the productivity and quality of spearmint $\left(1^{s t}\right.$ and $2^{\text {nd }}$ experiments) and geranium $\left(3^{\text {rd }}\right.$ and $4^{\text {th }}$ experiments).

The main experiment and the chemical properties of the tested soil were determined according to Jackson (1967) and Piper (1950) and presented in Table (1).

Each experiment of spearmint consisted of six weed control treatments as follows:

1- Oxyfluorfen (2-chloro -1- (3- ethoxy -4nitrophenooxy) 4- (trifluoromethyl) benzene known commercially as Roal $24 \%$ EC, was applied at $750 \mathrm{~cm}^{3}$ liter/fed. as pretransplanting.

2- Clethodim $(\neq)$-2- [ 1-(ethoxyimino) butyl ] 5- [ 2-(ethylthio) propyl ] -3-hydroxy -2cyclohexen -1- one (i)e, known commercially as Select super $12.5 \%$ EC, was applied at 500 $\mathrm{cm} 3$ liter/fed. after one month from transplanting. 
Table (1): Physical and chemical analyses of the soil of spearmint and geranium experiments at $(0-30 \mathrm{~cm}$.$) depth in 2014$ season.

\begin{tabular}{|c|c|c|c|c|c|c|c|c|c|c|}
\hline \multicolumn{11}{|c|}{ Particle size distribution } \\
\hline \multicolumn{2}{|c|}{ Sand \% } & \multicolumn{2}{|c|}{ Silt \% } & \multicolumn{2}{|c|}{ Clay \% } & \multicolumn{2}{|c|}{ Soil Texture } & \multicolumn{3}{|c|}{ Organic matter \% } \\
\hline \multicolumn{2}{|c|}{29.2} & \multicolumn{2}{|c|}{16.5} & \multicolumn{2}{|c|}{$54 . .3$} & \multicolumn{2}{|c|}{ Clay } & \multicolumn{3}{|c|}{2.1} \\
\hline \multicolumn{11}{|c|}{ Soluble ions $\left(\mathrm{mmolc}^{-1}\right)$} \\
\hline $\mathrm{SO}_{4}{ }^{2-}$ & $\mathrm{CI}^{-}$ & $\mathrm{HCO}^{3-}$ & $\mathrm{CO}_{3}{ }^{2-}$ & $\mathrm{K}^{+}$ & $\mathrm{Na}^{+}$ & $\mathrm{Mg}^{2+}$ & $\mathrm{Ca}^{2+}$ & $\begin{array}{c}\text { Ec; } \\
\mathrm{ds} / \mathrm{m}\end{array}$ & $\begin{array}{c}\mathrm{pH} \\
(1: 2.5)\end{array}$ & $\mathrm{CaCO}_{3}$ \\
\hline 43.2 & 7.25 & 0.55 & 0.00 & 3.00 & 8.2 & 14.1 & 25.7 & 4.8 & 8.01 & 3.56 \\
\hline
\end{tabular}

3-Pendimethalin (N-(1-ethylpropyl)-3,4 dimethyl-2,6-dinitrobenzenamin) known commercially as Stomp extra $45.5 \%$ CS was applied at rate 1.7 liter/fed. as pretransplanting.

4-Butralin(4-(1,1-dimethylethyl)-N-(1methylpropyl) -2,6-dinitrobenzenamin) known commercially as Amex $48 \%$ EC was applied at rate 2.5 liter/fed. as pretransplanting for first and second experiments (spearmint).

5- Hand hoeing three times with 15 days intervals, which begins after one month from transplanting.

6- Unweeded check (control)

In the first season (2014-2015), spearmint cuttings were planted on March $24^{\text {th }}$ and spaced at $25 \mathrm{~cm}$. The plants were harvested on July $7^{\text {th }}$ and October $15^{\text {th }}$ for the first and second cuts, respectively.

In the second season (2015-2016), spearmint was planted on March $30^{\text {th }}$ and the plants were harvested on July $7^{\text {th }}$ and October $8^{\text {th }}$ for the first and second cuts, respectively.

\section{1. geranium experiments}

Each experiment of geranium consisted of six weed control treatments as follows:

1- Oxyfluorfen, commercially known as Roal $24 \%$ EC, was applied at $750 \mathrm{~cm}^{3}$ liter/fed. as pre-transplanting.

2- Clethodim, commercially known as Select super $12.5 \%$ EC, was applied at $500 \mathrm{~cm}^{3}$ liter/fed. after one month from transplanting.

3- Pendimethalin, commercially known as Stomp extra $45.5 \%$ CS applied at rate 1.7 liter/fed. as pre-transplanting.

4- Mulching with one layer of black plastic sheets $80 \mathrm{U}$ diameter.

5- Hand hoeing three times with 15 days intervals, beginning 1 month after transplanting.

6- Unweeded check (control).
In the first season (2014-2015), terminal cuttings of geranium were planted on November $11^{\text {th }}$ and spaced at $25 \mathrm{~cm}$. The plants were harvested on May $16^{\text {th }}$ and October $4^{\text {th }}$ for the first and second cuts, respectively.

In the second season, geranium cuttings were transplanted on November $10^{\text {th }}$. The plants were harvested on May $20^{\text {th }}$ and October $4^{\text {th }}$ for the first and second cuts, respectively.

The treatments of spearmint and geranium experiments were arranged in a randomized complete block design with four replicate according to Gomez and Gomez (1984). The plot area was $10.5 \mathrm{~m}^{2}$ (3.5m length $\times 3 \mathrm{~m}$ width). The agriculture practices i.e., fertilization; irrigations; pest and diseases control were managed in accordance with the local recommendation for both crops. The soil texture of the experiment sites was clay in these two field experiments. The collected data on the two crops were recorded as follows:

\subsubsection{Weed characters}

Weeds were hand pulled at random from one square meter from of all the plots of spearmint and geranium at 15 days from last treatment, classified into three categories (grassy, broadleaved and total weeds) and dried in an oven at $70{ }^{\circ} \mathrm{C}$ until constant weight then the dried weeds were weighed. Weeds control was evaluated in the form of percentage reduction $(\mathrm{R} \%)$ in the dry weight of each individual species of weeds as well as the total weeds. Percentage reduction (R\%) was calculated according to Topps and Wain (1957) formula as $\mathrm{R} \%=(\mathrm{A}-\mathrm{B}) / \mathrm{A} * 100$

Where: $A=$ the dry weight of weeds in the control.

$\mathrm{B}=$ the dry weight of weeds in the treated plot.

\subsubsection{Growth characters and yield components}

At the harvest time, samples of spearmint and geranium plants were randomly collected from each plot to study the following characters:

1- Plant height $(\mathrm{cm})$.

2- Number of branches/plant. 
3- Herb fresh weight (g/plant) of aerial parts.

4- Yield of fresh herb/fed. was calculated according to plant fresh weight for plant $\times 25000$ (No. of plants/fed).

5- Volatile oil percentage was determined in fresh herb according to the British Pharmacopoeia (1963).

6- Volatile oil yield $(\mathrm{ml} / \mathrm{plant})=$ herb fresh weight per plant $\times$ oil $\%$ in fresh herb.

7- Oil yield/ fed. was calculated by multiplying oil yield g/plant $\times 25000$ (No. of plants/fed.).

\subsubsection{Oil constituents of spearmint and} geranium

Oil samples of the two corps used in this investigation were obtained using steam distillation in the second cut of the second season (Guenther 1961) and analyzed using Gas liquid Chromatography(GLC), to determine their constituents according the methods described by Bunzen et al. (1969) and Hoftman (1967).

\subsubsection{Herbicides residues}

The herbicides residues of Amex, Stomp, Roal and Select super in fresh herb were analyzed by GLC according to Nguyen et.al. (2008).

2.1.5. Economic feasibility of weed control in both crops (spearmint and geranium)

Economic evaluation due to weed control treatments was calculated according to Heady and Dillon (1961) as follows :

Gross income $=$ yield of oil $/ \mathrm{fed}(\mathrm{kg}) \times$ price of $\mathrm{kg}$ oil.

Gross margin $=$ gross income - total cost .

Benefit $/$ cost ratio $=$ gross income $/$ total cost.

2.1.6.Statistical analysis:
Mean values of each experiment were subject to the analysis of variance to test the significance as described by Gomez and Gomez (1984). Duncan means separation test and correlation were detected by using Mstat C ver.4 software.

\section{RESULTS AND DISCUSSIONS}

3.1. Effect of weed control treatments on weeds and spearmint yield and its components.

\subsubsection{On weeds}

The existed weed flora species in the experimental field during 2014 and 2015 seasons were Amaranthus viridis, Partulaca olracea, Bidens bipinnata, Ammi majus, Capsella bursapastoris, Euphorbia geniculate and Rumex dentatus as annual broad leaf weeds with infestation rates 0.97 and 0.45 ton dry weight ./fed in the first and the second seasons, respectively and Seratia viridis, Digitatria sanguinalis. Echinochloa colonum and Phalris minor as annual grassy weeds with infestations rates 0.43 and 0.24 ton dry weight ./fed. in both seasons, respectively.

Results in Table (2) showed significant decreases in the dry weight of the two categories of annual weeds as mentioned above by all weed control treatments in both seasons. The effectiveness of the weed control treatments on reducing the dry weight of the broadleaf weed, grassy weeds and their total could be arranged in a descending order as follows: Stomp at $1.7 \mathrm{l} / \mathrm{fed}$ by $93.9,89.9$ and $92.7 \%$, respectively; Amex at 2, .5 1/fed by $93.9,89.592 .6 \%$, respectively; Roal at $750 \mathrm{~cm}^{3} / \mathrm{fed}$ by $93.4,89.2$ and $92.1 \%$,

Table (2); Effect of weed control treatments on dry weight of grassy, broad leaf and their total $\mathrm{g} / \mathrm{m}^{2}$ during 2014 and 2015 seasons.

\begin{tabular}{|c|c|c|c|c|c|c|c|c|c|c|c|c|}
\hline \multirow[b]{3}{*}{$\begin{array}{c}\text { Weed control } \\
\text { treatments } \\
\text { Rate/fed }\end{array}$} & \multicolumn{6}{|c|}{2014} & \multicolumn{6}{|c|}{2015} \\
\hline & \multicolumn{6}{|c|}{ The dry weight of the annual weeds $(\mathrm{g} / \mathrm{m})$} & \multicolumn{6}{|c|}{ The dry weight of the annual weeds $(\mathrm{g} / \mathrm{m})$} \\
\hline & 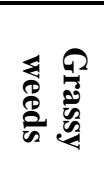 & dQ & 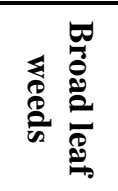 & dQ & 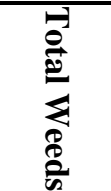 & 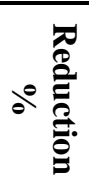 & 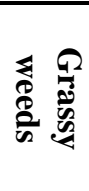 & ơ & 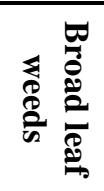 & ơ & 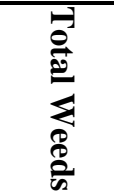 & 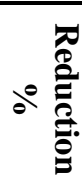 \\
\hline Roal at $750 \mathrm{~cm}^{3}$ & $11.0 \mathrm{~b}$ & 89.2 & $15.3 \mathrm{~b}$ & 93.4 & $26.3 \mathrm{c}$ & 92.1 & $5.3 \mathrm{bc}$ & 90.8 & $8.7 \mathrm{~b}$ & 91.8 & $14.0 \mathrm{e}$ & 91.4 \\
\hline Select at $500 \mathrm{~cm}^{3}$ & $5.7 \mathrm{c}$ & 94.4 & $225.3 \mathrm{a}$ & 0.03 & $231.0 \mathrm{~b}$ & 30.7 & $4.7 \mathrm{c}$ & 91.9 & $99.0 \mathrm{a}$ & 0.07 & $103.7 \mathrm{~b}$ & 36.8 \\
\hline Stomp at 1.71 & $10.3 b$ & 89.9 & $14.0 \mathrm{~b}$ & 93.9 & $24.3 \mathrm{c}$ & 92.7 & $4.7 \mathrm{c}$ & 91.9 & $8.7 \mathrm{~b}$ & 91.8 & $13.4 \mathrm{c}$ & 91.9 \\
\hline Amex at 2.51 & $10.7 \mathrm{~b}$ & 89.5 & $14.0 \mathrm{~b}$ & 93.9 & $24.7 \mathrm{c}$ & 92.6 & $5.3 \mathrm{bc}$ & 90.8 & $8.3 \mathrm{~b}$ & 92.2 & $13.6 \mathrm{c}$ & 91.7 \\
\hline Hoeing three times & $11.3 \mathrm{~b}$ & 88.9 & $16.0 \mathrm{~b}$ & 93.1 & $27.3 \mathrm{c}$ & 91.8 & $5.7 \mathrm{~b}$ & 90.2 & $9.7 \mathrm{~b}$ & 90.9 & $15.4 \mathrm{c}$ & 90.7 \\
\hline Control & $102.0 \mathrm{a}$ & - & $231.3 \mathrm{a}$ & - & $333.3 \mathrm{a}$ & - & $57.7 \mathrm{a}$ & - & $106.3 \mathrm{a}$ & - & $164.0 \mathrm{a}$ & - \\
\hline
\end{tabular}


respectively; hand hoeing at three times by 93.1, 88.9 and $91,3.7 \%$, respectively, and Select at $500 \mathrm{~cm}^{3} /$ fed by $0.03,94.4$ and $30.7 \%$, respectively, compared to the untreated check in the first season. Similar results were obtained in the second season. Where the dry weight of broadleaf weeds, grasses and their total reached 91.8, 91.9 and $91.9 \%$, respectively, by Stomp extra at 1.7 1/fed.; $92.2,90.8$ and $91.7 \%$ respectively by Amex at 2.5 1/fed.; 91.8, 90.8 and 91.4 respectively, by Roal at $750 \mathrm{~cm}^{3} / \mathrm{fed}$.; $90.9,90.2$ and $90.7 \%$, respectively, by hand hoeing at three times and $0.07,91.9$ and $36.8 \%$, respectively, by Select super at $500 \mathrm{~cm}^{3} /$ fed. Compared to the untreated control. Romanowski et al. (1980) found that Pendimethalin at 4.0 1/ha effectively controlled weeds without adverse effect on the raspberry plants.

\subsubsection{Growth characters and yield of spearmint.}

The growth of spearmint plants positively responded to weed control treatments. Thus, the values of plants height $(\mathrm{cm})$, branches No. and fresh weight (gm/plant) increased due to weed control treatments (Table 3). The highest increase in this respect was noticed in the case of Stomp at $1.71 /$ fed. where the values were 58.3 , $50.0 \mathrm{~cm}, \quad 20.0, \quad 18.3$ branches/plant, 193.6, $172.6 \mathrm{gm} / \mathrm{plant}, 4.84$ and $4.32 \mathrm{ton} / \mathrm{fed}$. for plant height, branches No., fresh weight $\mathrm{gm} /$ plant and herb yield ton/fed in the $1^{\text {st }}$ and $2^{\text {nd }}$ cut for the first season respectively, the highest response of spearmint growth after Stomp application was followed by Roal at $750 \mathrm{~cm}^{3} / \mathrm{fed}$. On the other hand, the least growth was in the case of the control plants (untreated with any weed control method).

The same trend was evident in the $2^{\text {nd }}$ season as indicated in (Table) 3. The application of Stomp at $1.7 \mathrm{l} / \mathrm{fed}$ gave the best result for spearmint growth. In the $1^{\text {st }}$ and the $2^{\text {nd }}$ cut in the second season. This treatment induced the highest growth in terms of plant height,branches No.,fresh weight $\mathrm{gm} /$ plant and yield of fresh herb/fed.

The values were $86.3,67 \mathrm{~cm}, 19.7,18.7$ branches/plant, 294, $271 \mathrm{gm} /$ plant, 7.35 and 6.80 ton/fed for the $1^{\text {st }}$ and the $2^{\text {nd }}$ cut respectively. Also, the annual herb yield recorded the highest values in this respect 9.16 and 14.15 ton/fed in the $1^{\text {st }}$ and the $2^{\text {nd }}$ season respectively.

As indicated previously in the $1^{\text {st }}$ season, Roal also gave high response followed the Stomp treatment with regard the spearmint growth. The recorded values were $84,63.3 \mathrm{~cm}$,
17.7, 16.3 branches/plant, 272, $256 \mathrm{gm} /$ plant, 6.80 and 6.40 ton/fed. In the $1^{\text {st }}$ and the $2^{\text {nd }}$ cut respectively, Also, the control (untreated plants) gave the least growth as tabulated in (Table 3 ).

\subsubsection{Essential oil of spearmint}

It was noticed that spearmint essential oil production was enhanced by weed control treatments (Table) 4. This enhancement hold true in the two seasons. Stomp application was found to be the effective treatment in this respect. So, the values of the essential oil content $(\%)$, yield (ml/plant), and yield oil 1/fed. recorded a significant increase due to Stomp application, in comparison with the untreated plants (control). The recorded values of Stomp treatment in the $1^{\text {st }}$ and the $2^{\text {nd }}$ cut in the first season were $0.45,0.33 \%, 0.87,0.56 \mathrm{ml} / \mathrm{plant}, 21.75$ and $14 \mathrm{l} / \mathrm{fed}$.

The results of the $1^{\text {st }}$ season were confirmed in the $2^{\text {nd }}$ season. Accordingly, Stomp treatment gave the best results in the $1^{\text {st }}$ and the $2^{\text {nd }}$ cut as shown in Table (4). The highest essential oil content, oil yield $\mathrm{ml} /$ plant and yield per fed. were recorded in case of Stomp treatment. The values were $0.37,0.29 \%, 1.1,0.79 \mathrm{ml} / \mathrm{plant}$, 27.50 and $19.75 \mathrm{l} / \mathrm{fed}$. The annual yield of essential oil of spearmint plants showed the same trend i.e. Stomp treatment producted the highest oil yield in the two seasons 35.75 and $47.25 \mathrm{~L} / \mathrm{fed}$., respectively.

The least record was obtained in the case of the control plants.

\subsubsection{Chemical composition of spearmint essential oil}

Volatile oil samples were taken from the oil obtained in the $2^{\text {nd }}$ cut of the second season and analyzed using gas liquid chromatography (GLC), to determine the oil components i.e. $\alpha, \beta-$ pinene, Limonene, Cymene, Cineol, Terpinene, Carvone, $\beta$-caryophyllene an Eugenol, as shown in Table (5) and Figs (1-6). Actually, Carvone was the main component of spearmint essential oil, its presence in the oil is Limonene dependent, so the obtained results showed that the application of Roal at $750 \mathrm{~cm}^{3} /$ fed. gave the highest percentage of Carvone $(71.22 \%)$ while Limonene was absent. On the other hand the lowest percentage of Carvone (49.08 \%) was obtained in case of Amex at $2.5 \mathrm{1} / \mathrm{fed}$. whereas, the Limonene content attained(10.52\%) due to this treatment.

\subsubsection{Residues analysis}

From Figs (7-14) and Table (6) the Gas Liquid Chromatography showed no signal to the 


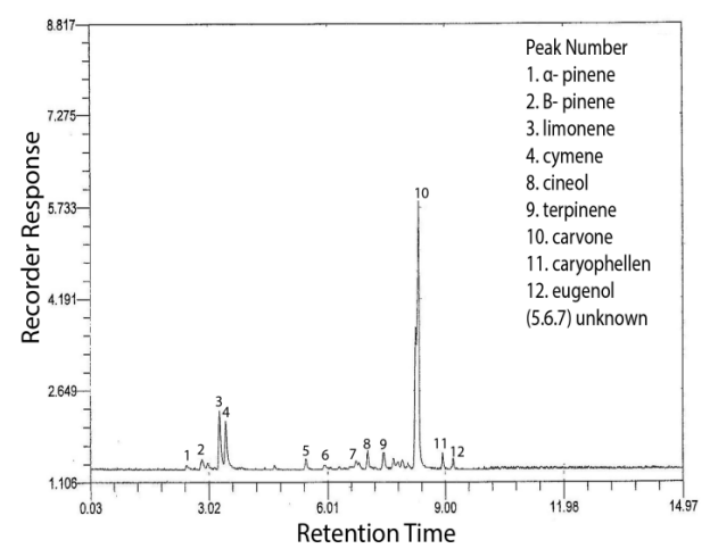

Fig 1: Chromatogram of Spearmint essential oil (control)

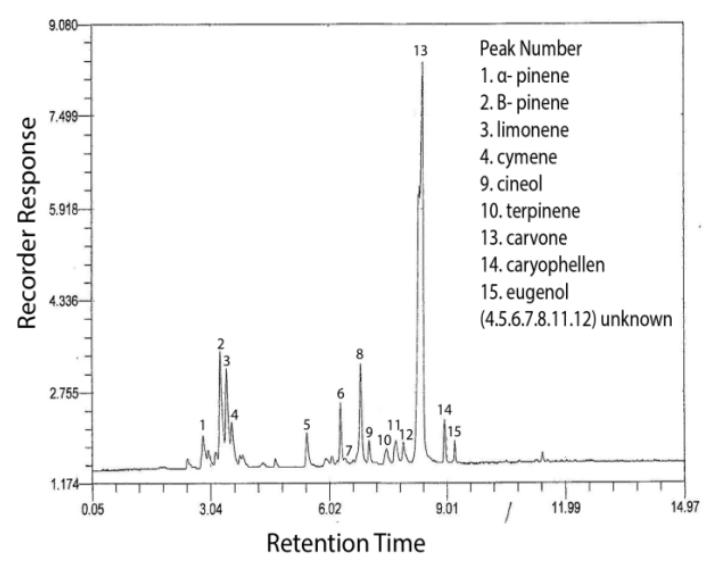

Fig 3: Chromatogram of Spearmint essential oil (Roal a $750 \mathrm{~cm}^{3}$ )

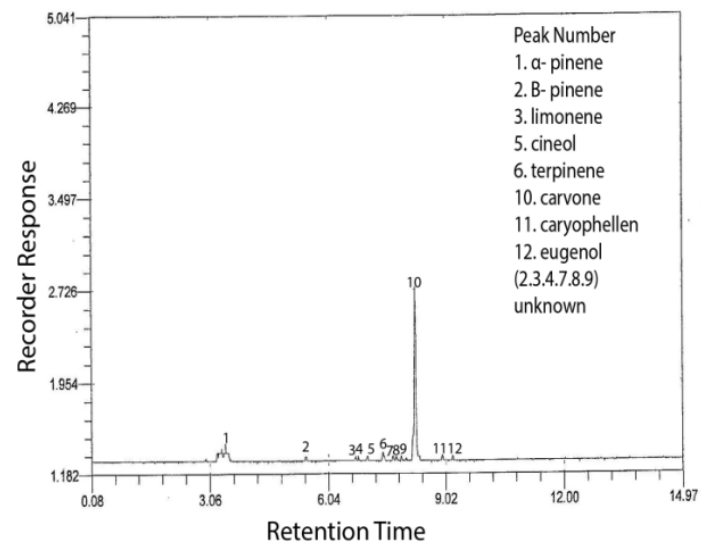

Fig 5: (Stomp at $1.7 \mathrm{l} / \mathrm{fed}$ )

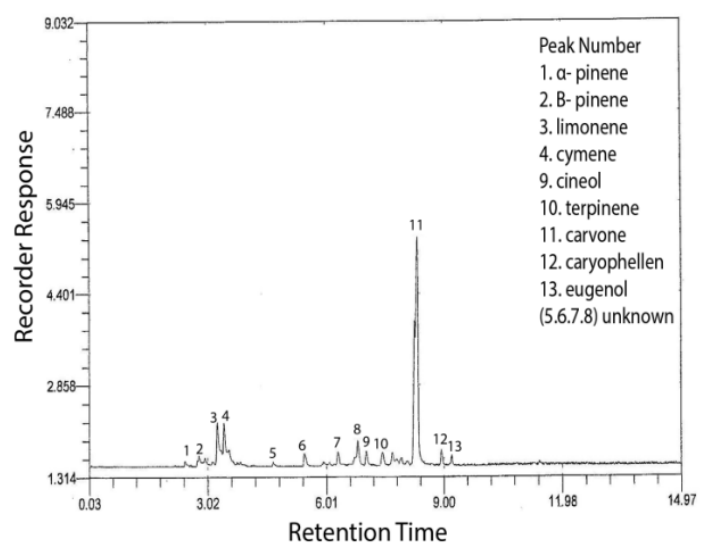

Fig 2: Chromatogram of Spearmint essential oil (Hoeing three times)

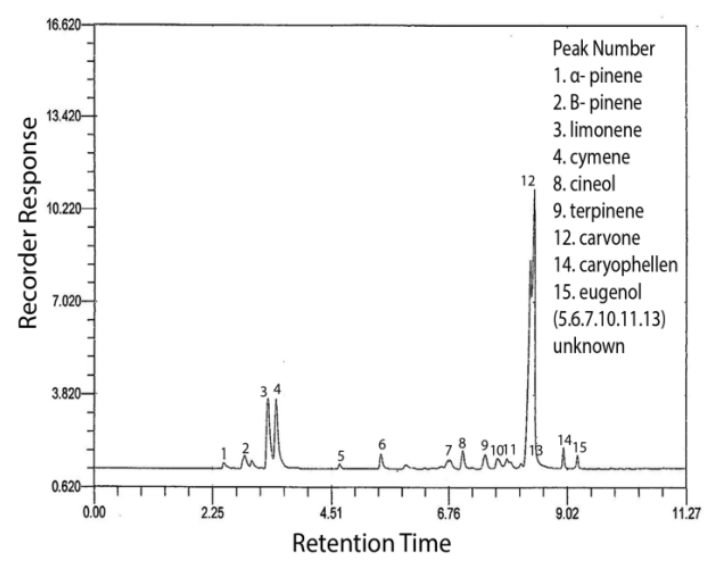

Fig 4: GLC (Amex at 2.51/fed)

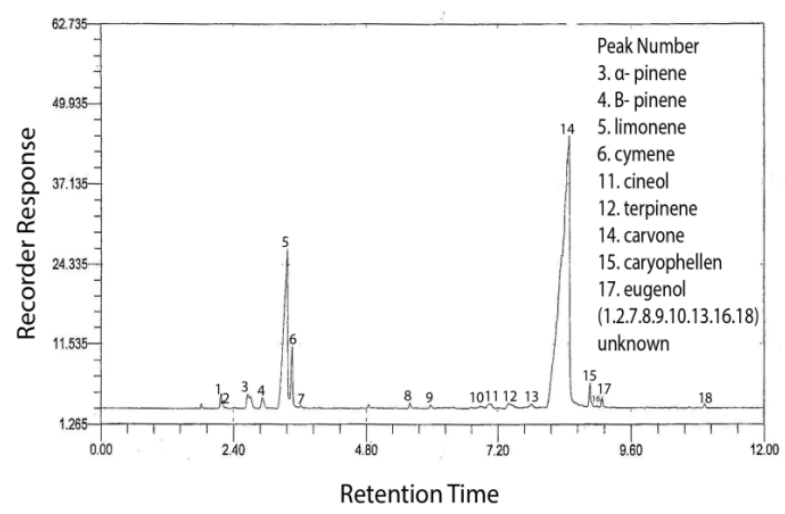

Fig 6: (Select super at $500 \mathrm{~cm}^{3}$ ) 
Table (3): Effect of weed control treatments on growth characters and yield of spearmint during 2014-2015 and 20152016.

\begin{tabular}{|c|c|c|c|c|c|c|c|c|c|c|}
\hline \multirow{3}{*}{$\begin{array}{c}\text { Characteristics } \\
\text { Weed Control } \\
\text { Treatments rate/fed }\end{array}$} & \multicolumn{10}{|c|}{ 2014-2015 Season } \\
\hline & \multicolumn{2}{|c|}{$\begin{array}{l}\text { Plant height } \\
(\mathrm{cm})\end{array}$} & \multicolumn{2}{|c|}{$\begin{array}{c}\text { No. of } \\
\text { branches/plant }\end{array}$} & \multicolumn{3}{|c|}{ Herb fresh yield gm/plant } & \multicolumn{3}{|c|}{ Herbage yield fed. (ton/fed) } \\
\hline & $1^{\text {st }}$ cut & $2^{\text {nd }}$ cut & $1^{\text {st }} \mathrm{cut}$ & $2^{\text {nd }}$ cut & $1^{\mathrm{st}} \mathrm{cut}$ & $2^{\text {nd }}$ cut & Total & $1^{\text {st }}$ cut & $2^{\text {nd }}$ cut & Total \\
\hline Roal & $52.0 \mathrm{~b}$ & $48.0 \mathrm{~d}$ & $17.7 \mathrm{~b}$ & $16.7 \mathrm{c}$ & $173.7 \mathrm{~b}$ & $155.5 \mathrm{~b}$ & $329.2 \mathrm{~b}$ & $4.34 \mathrm{~b}$ & $3.89 \mathrm{a}$ & $8.19 b$ \\
\hline $\begin{array}{l}\text { Select super at } 500 \\
\mathrm{~cm}^{3}\end{array}$ & $43.7 \mathrm{c}$ & $36.7 \mathrm{e}$ & $17.3 \mathrm{c}$ & $14.0 \mathrm{~d}$ & $56.0 \mathrm{e}$ & $53.7 \mathrm{~d}$ & $109.7 \mathrm{e}$ & $1.40 \mathrm{e}$ & $1.34 \mathrm{c}$ & $2.74 \mathrm{e}$ \\
\hline Stomp at 1.71 & $58.3 \mathrm{a}$ & $50.0 \mathrm{a}$ & $20.0 \mathrm{a}$ & $18.3 \mathrm{a}$ & $193.6 \mathrm{a}$ & & & & & $.16 \mathrm{a}$ \\
\hline Amex at 2.51 & $50.7 \mathrm{~b}$ & $46.0 \mathrm{~b}$ & $18.7 \mathrm{~b}$ & $17.0 \mathrm{~b}$ & $117.6 \mathrm{~d}$ & $114.4 \mathrm{c}$ & $232.0 \mathrm{c}$ & $2.94 \mathrm{~d}$ & $2.86 \mathrm{~b}$ & $5.80 \mathrm{~d}$ \\
\hline Hoeing three times & $50.0 \mathrm{~b}$ & $43.0 \mathrm{c}$ & $16.7 \mathrm{c}$ & $15.7 \mathrm{c}$ & $125.7 \mathrm{c}$ & $117.3 \mathrm{c}$ & $243.0 \mathrm{~d}$ & $3.14 \mathrm{c}$ & $2.93 b$ & $6.07 \mathrm{c}$ \\
\hline \multirow[t]{2}{*}{ Control } & $35.0 \mathrm{~d}$ & $33.0 \mathrm{f}$ & $13.0 \mathrm{~d}$ & $12.7 \mathrm{e}$ & $33.0 \mathrm{f}$ & $30.1 \mathrm{e}$ & $63.1 \mathrm{f}$ & $0.83 \mathrm{f}$ & $0.75 \mathrm{~d}$ & $1.64 \mathrm{f}$ \\
\hline & \multicolumn{10}{|c|}{ 2015-2016 season } \\
\hline Roal at $750 \mathrm{~cm}^{3}$ & $84.0 \mathrm{~b}$ & $63.3 b$ & $17.7 b c$ & $16.3 \mathrm{~b}$ & $272.0 \mathrm{~b}$ & $256.1 \mathrm{~b}$ & $528.1 \mathrm{~b}$ & $6.80 \mathrm{~b}$ & $6.40 \mathrm{~b}$ & $13.2 \mathrm{~b}$ \\
\hline $\begin{array}{l}\text { Select super at } 500 \\
\mathrm{~cm}^{3}\end{array}$ & $72.0 \mathrm{~d}$ & $56.3 \mathrm{~d}$ & $18.0 \mathrm{~b}$ & $13.3 \mathrm{~d}$ & $239.1 \mathrm{e}$ & $196.8 \mathrm{e}$ & $435.9 \mathrm{e}$ & $5.98 \mathrm{e}$ & $4.92 \mathrm{e}$ & $10.9 \mathrm{e}$ \\
\hline Stomp at 1.71 & $86.3 \mathrm{a}$ & $67.0 \mathrm{a}$ & $19.7 \mathrm{a}$ & $18.7 \mathrm{a}$ & $294.1 \mathrm{a}$ & $271.9 a$ & & & $6.80 \mathrm{a}$ & $14.15 \mathrm{a}$ \\
\hline Amex at 2.51 & $83.3 \mathrm{~b}$ & $61.3 \mathrm{c}$ & $18.0 \mathrm{~b}$ & $14.0 \mathrm{c}$ & $247.0 \mathrm{~d}$ & $238.6 \mathrm{c}$ & $485.6 \mathrm{c}$ & $6.18 \mathrm{~d}$ & $5.97 \mathrm{c}$ & $12.15 \mathrm{c}$ \\
\hline Hoenig three times & $78.0 \mathrm{c}$ & $58.0 \mathrm{~d}$ & $17.0 \mathrm{c}$ & $13.3 \mathrm{~d}$ & $262.5 \mathrm{c}$ & $200.9 d$ & $463.4 d$ & $6.56 \mathrm{c}$ & $5.02 \mathrm{~d}$ & $11.58 \mathrm{~d}$ \\
\hline Control & $50.7 \mathrm{~d}$ & $40.3 \mathrm{e}$ & $10.3 \mathrm{~d}$ & $10.0 \mathrm{e}$ & $45.5 \mathrm{f}$ & $43.7 \mathrm{f}$ & $89.2 \mathrm{f}$ & $1.11 \mathrm{f}$ & $1.05 \mathrm{f}$ & $2.16 \mathrm{f}$ \\
\hline
\end{tabular}

Table (4): Effect of weed control treatments on essential oil of spearmint during 2014 and 2015 seasons.

\begin{tabular}{|c|c|c|c|c|c|c|c|c|}
\hline \multirow{3}{*}{\begin{tabular}{|c|} 
Characteristics \\
\\
Weed Control \\
Treatments rate/fed
\end{tabular}} & \multicolumn{8}{|c|}{ 2014-2015 Season } \\
\hline & \multicolumn{2}{|c|}{ Volatile oil \% } & \multicolumn{3}{|c|}{ Volatile oil yield (ml/plant) } & \multicolumn{3}{|c|}{ yield oil (1/fed) } \\
\hline & $1^{\text {st }}$ cut & $\begin{array}{l}2^{\text {nd }} \\
\text { cut }\end{array}$ & $1^{\text {st }}$ cut & $2^{\text {nd }}$ cut & Total & $1^{\text {st }}$ cut & $2^{\text {nd }}$ cut & Total \\
\hline Roal at $750 \mathrm{~cm}^{3}$ & $0.33 b$ & $0.3 \mathrm{a}$ & $0.57 \mathrm{~b}$ & $0.47 \mathrm{~b}$ & $1.04 \mathrm{~b}$ & $14.25 b$ & $10.0 \mathrm{~b}$ & $26.0 \mathrm{~b}$ \\
\hline Select super at $500 \mathrm{~cm}^{3}$ & $0.33 b$ & $0.3 \mathrm{~b}$ & $0.18 \mathrm{~d}$ & $0.17 \mathrm{~d}$ & $0.35 \mathrm{~d}$ & $4.58 \mathrm{~d}$ & $4.25 \mathrm{~d}$ & $8.75 \mathrm{~d}$ \\
\hline Stomp at 1.71 & $0.45 \mathrm{a}$ & $0.33 \mathrm{a}$ & $0.87 \mathrm{a}$ & $0.56 \mathrm{a}$ & $1.43 \mathrm{a}$ & $21.75 \mathrm{a}$ & $14.0 \mathrm{a}$ & $35.75 \mathrm{a}$ \\
\hline Amex at 2.51 & $0.32 \mathrm{bc}$ & $0.27 \mathrm{c}$ & $0.38 \mathrm{c}$ & $0.31 \mathrm{~b}$ & $0.69 \mathrm{c}$ & $9.5 \mathrm{c}$ & $7.75 \mathrm{c}$ & $17.25 \mathrm{c}$ \\
\hline Hoeing three times & $0.31 \mathrm{c}$ & $0.25 \mathrm{c}$ & $0.39 \mathrm{c}$ & $0.29 \mathrm{c}$ & $0.68 \mathrm{c}$ & $9.75 \mathrm{c}$ & $7.25 \mathrm{c}$ & $17.0 \mathrm{c}$ \\
\hline \multirow[t]{2}{*}{ Control } & $0.29 \mathrm{~d}$ & $0.25 \mathrm{c}$ & $0.09 \mathrm{e}$ & $0.07 \mathrm{~d}$ & $016 \mathrm{e}$ & $2.25 \mathrm{e}$ & $1.75 \mathrm{e}$ & $4.0 \mathrm{e}$ \\
\hline & \multicolumn{8}{|c|}{ 2015-2016 season } \\
\hline Roal at $750 \mathrm{~cm}^{3}$ & $0.35 \mathrm{a}$ & $0.29 \mathrm{a}$ & $0.96 b$ & $0.75 \mathrm{a}$ & $1.71 \mathrm{~b}$ & $24.00 \mathrm{~b}$ & $18.75 \mathrm{a}$ & $42.75 b$ \\
\hline Select super at $500 \mathrm{~cm}^{3}$ & $0.33 b$ & $0.24 \mathrm{~b}$ & $0.79 \mathrm{~d}$ & $0.49 \mathrm{c}$ & $1.28 \mathrm{~d}$ & $19.75 d$ & $12.25 \mathrm{c}$ & $32.00 \mathrm{e}$ \\
\hline Stomp at 1.71 & $0.37 \mathrm{a}$ & $0.29 \mathrm{a}$ & $1.1 \mathrm{a}$ & $0.79 \mathrm{a}$ & $1.89 \mathrm{a}$ & $27.50 \mathrm{a}$ & $19.75 \mathrm{a}$ & $47.25 \mathrm{a}$ \\
\hline Amex at 2.51 & $0.37 \mathrm{a}$ & $0.29 \mathrm{a}$ & $0.9 \mathrm{bc}$ & $0.68 \mathrm{~b}$ & $1.58 \mathrm{c}$ & $22.50 \mathrm{c}$ & $17.00 \mathrm{~b}$ & $39.50 \mathrm{c}$ \\
\hline Hoenig three times & $0.33 b$ & $0.25 b$ & $0.88 \mathrm{c}$ & $0.50 \mathrm{c}$ & $1.38 \mathrm{~d}$ & $22.00 \mathrm{c}$ & $12.50 \mathrm{c}$ & $34.50 \mathrm{~d}$ \\
\hline Control & $0.29 \mathrm{c}$ & $0.21 \mathrm{c}$ & $0.10 \mathrm{e}$ & $0.08 \mathrm{~d}$ & $0.18 \mathrm{e}$ & $2.5 \mathrm{e}$ & $2.00 \mathrm{~d}$ & $4.5 \mathrm{f}$ \\
\hline
\end{tabular}

four herbicides used (not detected). These four herbicides (Butralin, Pendimethalin, Oxyfluorfen and Clethodim) were degraded in the spearmint plants and the GLC coul not read any values. The residues level of the four herbicides depended on the nature of plant. Moreover, some herbicides were rapidly degraded in the open field by sunlight and its stability in the soil having many species of microorganisms and different levels of acidity and alkalinity in addition the hoeing of of the soil. 


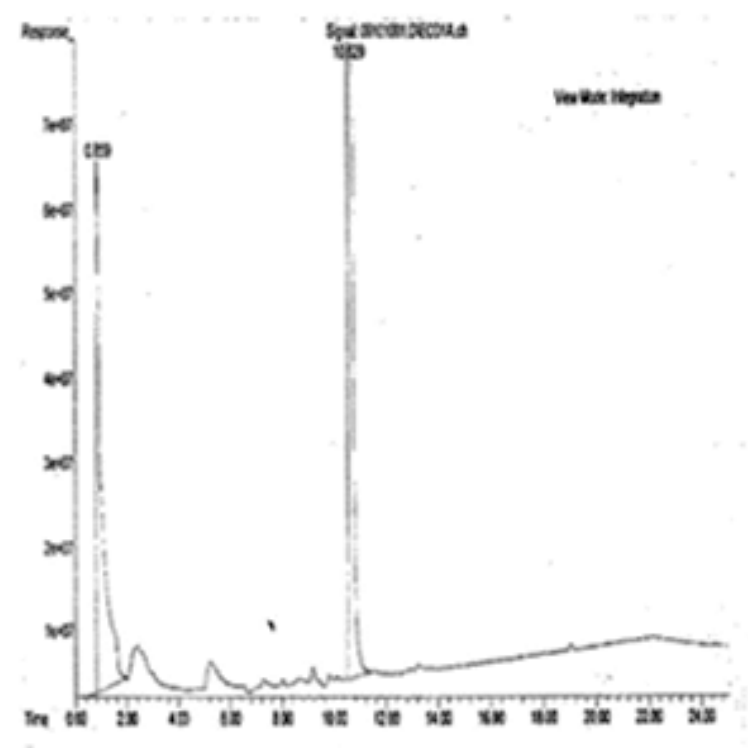

Fig (7) : Standard of Stomp extra

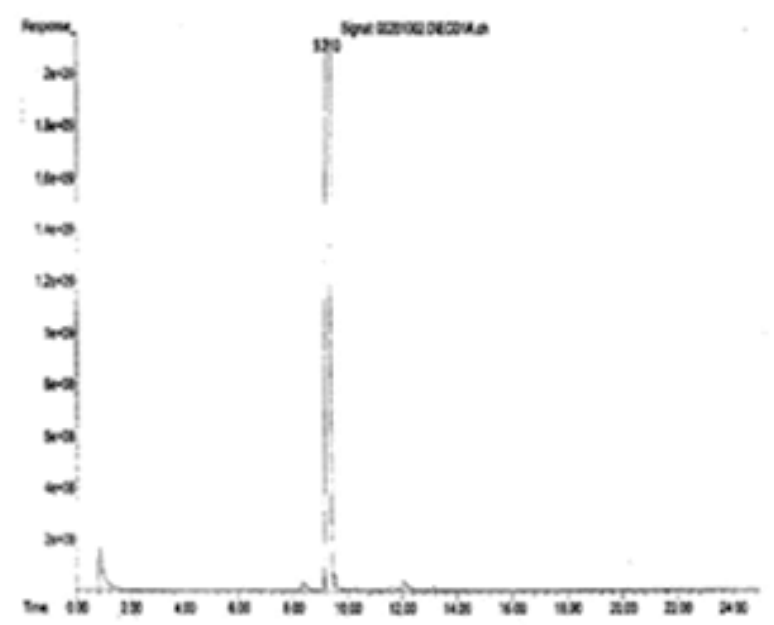

Fig (9): Standard of Amex

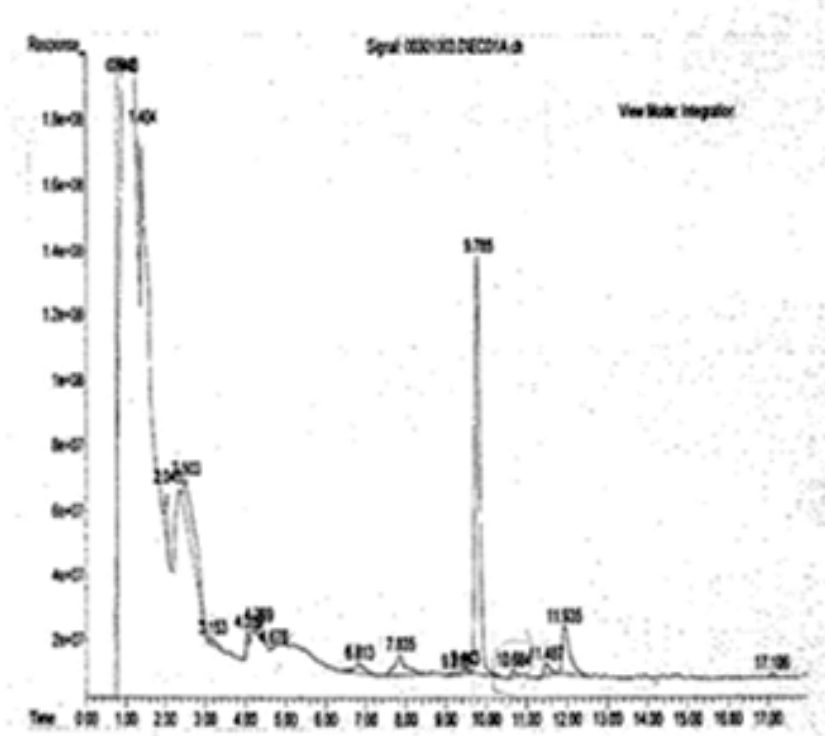

Fig (8) : Residual of Stomp extra in spearmint

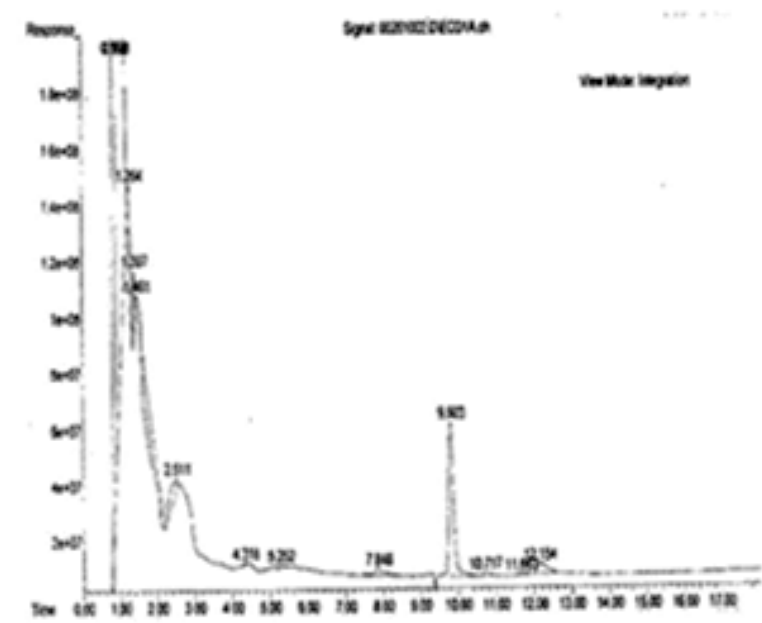

Fig (10): Residual of Amex in spearmint

Table (5): Chemical composition of oil in spearmint as affected by weed control treatments.

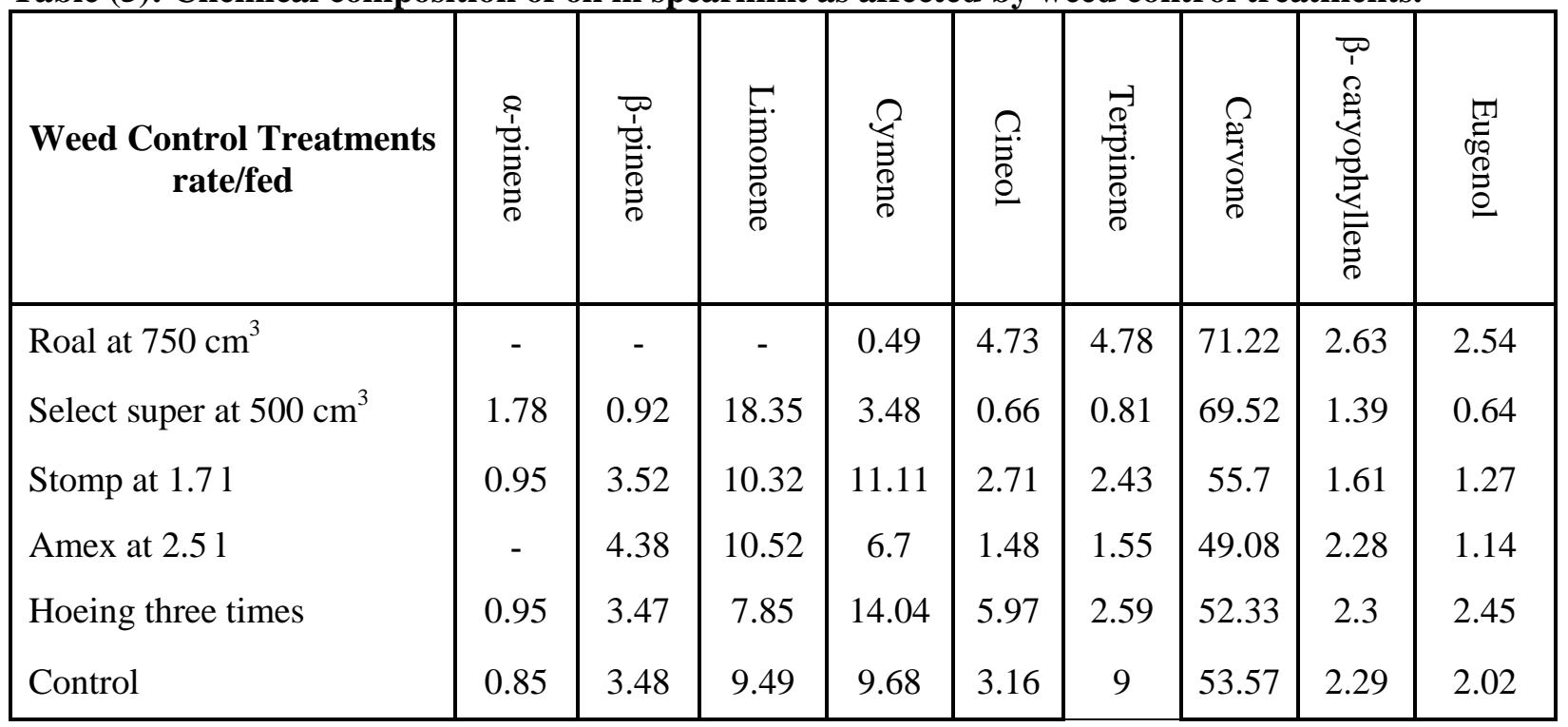


Table (6): Calibration of butralin, pendimethalin, and Oxyfluorfen and Clethodim parameters:

\begin{tabular}{|l|c|c|}
\hline \multicolumn{1}{|c|}{$\begin{array}{c}\text { Herbicides } \\
\text { name }\end{array}$} & Residual (ppm) & $\begin{array}{c}\text { Max. Residue } \\
\text { Level }[\mathrm{mg} / \mathrm{kg}]\end{array}$ \\
\hline Pendimethalin & ND & 0.005 \\
\hline Butralin & ND & 0.02 \\
\hline Oxyflorfen & ND & 0.3 \\
\hline Clethodim & ND & 0.02 \\
\hline
\end{tabular}

ND $=$ Not detected

\subsubsection{Determination of economics for weed control in the spearmint plants}

Data in Table (7) show that the total cost of the weeded check was3.59 and 3.70 thS L.E. in 2014 and 2015 seasons, respectively, which is considered the fixed cost (land preparation, transplantation fertilization irrigation, insect control, harvesting and transportation), in addition; to the cost of the treatments on the others. In both seasons, Stomp at $1.7 \mathrm{l} / \mathrm{fed}$. gave the highest values of gross income, net benefit
It is notable from the data in Table (8) that the infestation rate for the whole season recorded (0.43 and 0.75 ton/fed.) and (0.3 and 0.7 ton/fed.) of the dry weight for grasses, broad leaf weeds, respectively, in both seasons approximately. Table (8) shows the means of dry weight of grassy, broadleaved and total annual weeds as affected by different herbicides and hand hoeing compared with the untreated treatment in both seasons. All herbicidal treatments and hand hoeing gave high significant reduction percentage on the dry weight of presented weeds in both seasons. Stomp extra at rate of $1.7 \mathrm{l} / \mathrm{fed}$. reduced broad leaf, grassy and their total by $95.0 \& 94.5$ and $92.7 \%$, respectively. The following treatments in the highest increasing percentage the previous respective characteristics were Roal at 750 $\mathrm{cm}^{3} /$ fed. by $92.2 \& 91.9$ and $92.1 \%$, respectively; Black plastic sheet by $90.4 \& 88.7$ and $89.8 \%$, respectively; hand hoeing at three times by $89.1 \& 87.7$ and $88.6 \%$, respectively, and Select super at $500 \mathrm{~cm}^{3} 26.1 \& 93.9$ and $50.9 \%$, respectively, compared to the untreated control in the first season. Similar results were obtained in the second season. The reduction in the dry wt. of broadleaf weeds, grasses and their

Table (7): Determination of economics for weed control in the spearmint plants:

\begin{tabular}{|l|c|c|c|c|c|c|c|c|}
\hline \multicolumn{1}{|c|}{ Seasons } & \multicolumn{4}{c|}{ 2014-2015 } & \multicolumn{3}{c|}{$2015-2016$} \\
Treatments Rate/fed & $\begin{array}{c}\text { Total } \\
\text { cost Ths. } \\
\text { L.E. }\end{array}$ & $\begin{array}{c}\text { Gross } \\
\text { income } \\
\text { Ths L.E. }\end{array}$ & $\begin{array}{c}\text { Net } \\
\text { Benefit } \\
\text { Ths L.E. }\end{array}$ & B/C & $\begin{array}{c}\text { Total } \\
\text { cost Ths. } \\
\text { L.E. }\end{array}$ & $\begin{array}{c}\text { Gross } \\
\text { income } \\
\text { Ths L.E. }\end{array}$ & $\begin{array}{c}\text { Net } \\
\text { Benefit } \\
\text { Ths } \\
\text { L.E. }\end{array}$ & $\begin{array}{c}\text { B/C } \\
\text { R. }\end{array}$ \\
\hline Roal at 750 cm $\mathrm{cm}^{3}$ & 3.69 & 13.1 & 9.41 & 3.58 & 3.8 & 21.38 & 17.58 & 5.62 \\
Select super at 500 cm ${ }^{3}$ & 3.72 & 4.38 & 0.66 & 1.18 & 3.83 & 16.0 & 12.17 & 4.18 \\
Stomp at 1.7 1 & 3.85 & 17.88 & 14.03 & 4.69 & 3.96 & 23.63 & 19.67 & 5.97 \\
Amex at 2.5 1 & 4.02 & 8.63 & 4.61 & 2.15 & 4.13 & 19.15 & 15.62 & 4.66 \\
Hoeing three times & 4.19 & 8.5 & 4.31 & 2.03 & 4.3 & 17.25 & 12.95 & 4.01 \\
Control & 3.59 & 2.00 & -1.59 & 0.58 & 3.7 & 2.25 & -1.45 & 0.61 \\
\hline
\end{tabular}

and the percentage of benefit/cost by $17.88 \&$ 14.03 thS LE and $4.69 \%$ and $23.63 \& 19.67$ thS LE and $5.97 \%$ respectively, in the first and second seasons Roal at $750 \mathrm{~cm}^{3} /$ fed. was the following treatment which increasing the respective previous economic values by $13.1 \&$ 9.41 thS and $3.58 \%$ and $21.38 \& 17.58$ thS LE and $5.62 \%$, respectively, in both seasons. Whilst, the rest treatments i.e, Amex at $2.5 \mathrm{l} / \mathrm{fed}$. hand hoeing three times and Select super at 500 $\mathrm{cm}^{3} / f$ f. were still superior of the previous economic value compared to unweeded check.

\subsection{Effect of weed control treatments on weeds and geranium yield and its components 3.2.1. On weeds}

total reached 94.6, 90.6 and $93.4 \%$, respectively, by Stomp extra at 1.71/fed.; $94.4 \& 90.6$ and $93.3 \%$, respectively by Roal at $750 \mathrm{~cm}^{3} / \mathrm{fed}$.; $90.5 \& 90.0$ and 90.4 , respectively, by black plastic sheet, $90.9 \& 85$ and $89.1 \%$, respectively, by hand hoeing at three times and 12.9, 89.6 and $35.8 \%$, respectively, by Select super at 500 $\mathrm{cm}^{3} / \mathrm{fed}$. compared to the untreated control. These results agree with (Kothari et al., 2002) who found that pre emergence application of pendimethalin $(0.75-1.00 \mathrm{~kg} / \mathrm{ha})$ or oxyfluorfen $(0.25 \mathrm{~kg} / \mathrm{ha})$, successive hand-weeding, hoeing, and mulching and three hand-weeding were highly effective in reducing weed density and dry weight and pendimethalin $(0.50 \mathrm{~kg} / \mathrm{ha})$ were 
Table (8)., Effect of weed control treatments in dry weight of grassy, broad leaf and total weed g/m $\mathrm{m}^{2} \mathrm{during} 2014$ and 2015 seasons.

\begin{tabular}{|c|c|c|c|c|c|c|c|c|c|c|c|c|}
\hline \multirow[b]{3}{*}{$\begin{array}{l}\text { Weed control } \\
\text { treatments } \\
\text { Rate/fed }\end{array}$} & \multicolumn{6}{|c|}{2014} & \multicolumn{6}{|c|}{2015} \\
\hline & \multicolumn{6}{|c|}{ The dry weight of the annual weeds $(\mathrm{g} / \mathrm{m})$} & \multicolumn{6}{|c|}{ The dry weight of the annual weeds $(\mathrm{g} / \mathrm{m})$} \\
\hline & 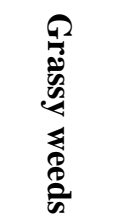 & 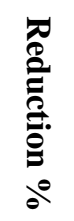 & 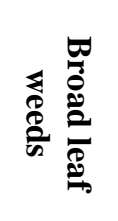 & 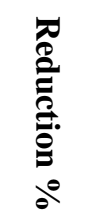 & 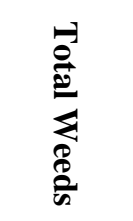 & 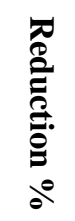 & 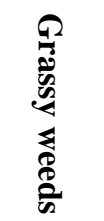 & 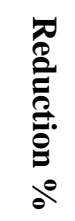 & 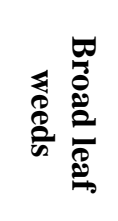 & 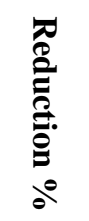 & 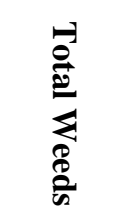 & 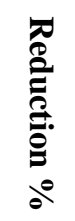 \\
\hline Roal at $750 \mathrm{~cm}^{3}$ & $8.3 \mathrm{CD}$ & 91.9 & $14.0 \mathrm{C}$ & s92.2 & 22.3DE & 92.1 & $6.7 \mathrm{C}$ & 90.6 & $9.3 \mathrm{C}$ & 94.4 & $16.0 \mathrm{D}$ & 93.3 \\
\hline Select at $500 \mathrm{~cm}^{3}$ & $6.3 \mathrm{D}$ & 93.9 & 132.7B & 26.1 & $139.0 \mathrm{~B}$ & 50.9 & $7.3 \mathrm{C}$ & 89.6 & 146.0B & 12.9 & $153.3 \mathrm{~B}$ & 35.8 \\
\hline Stomp at 1.71 & 5.7D & 94.5 & $9.0 \mathrm{C}$ & 95.0 & $14.7 \mathrm{E}$ & 94.8 & $6.7 \mathrm{C}$ & 90.6 & $9.0 \mathrm{C}$ & 94.6 & $15.7 \mathrm{D}$ & 93.4 \\
\hline Amex at 2.51 & $11.7 \mathrm{BC}$ & 88.7 & $17.3 \mathrm{C}$ & 90.4 & 29.0CD & 89.8 & $7.0 \mathrm{C}$ & 90.0 & $16.0 \mathrm{C}$ & 90.5 & $23.0 \mathrm{C}$ & 90.4 \\
\hline Hoeing three times & $12.7 \mathrm{~B}$ & 87.7 & $19.7 \mathrm{C}$ & 89.1 & $32.4 \mathrm{C}$ & 88.6 & 10.7B & 85.0 & $15.3 \mathrm{C}$ & 90.9 & $26.0 \mathrm{C}$ & 89.1 \\
\hline Control & $103.3 \mathrm{~A}$ & - & $179.7 \mathrm{~A}$ & - & $283.0 \mathrm{~A}$ & - & $\begin{array}{c}71.0 \\
\text { A }\end{array}$ & - & $167.7 \mathrm{~A}$ & - & $238.7 \mathrm{~A}$ & - \\
\hline
\end{tabular}

less effective in controlling the weed species in geranium. Mineta et al. (1997) reported that mulch removal in May and July led to a significant increase of summer annual weeds, especially Cyperus sp.

\subsubsection{Growth characters and yield of geranium}

The growth of geranium plants positively responded to weed control treatments. thus, the values of plant height $(\mathrm{cm})$, branches No. and fresh weight (gm/plant) increased due to weed control treatments. The highest increase in this respect was noticed in case of Stomp at $1.7 \mathrm{l} / \mathrm{fed}$. Table (9). The values were 105, $79.7 \mathrm{~cm}$, 12,14.3 branches/plant, 393.7, 365 gm/plant, 9.85 and 9.12 ton/fed. for plant height, branches No., fresh weight gm/plant and herb yield ton/fed. in the $1^{s t}$ and the $2^{\text {nd }}$ cut for the first season respectively. The highest response of geranium growth after Stomp application was followed by Roal at $750 \mathrm{~cm}^{3} / \mathrm{fed}$., on the other hand, the least growth was in the case of control plants (untreated with any weed control method).

The same trend was shown in the $2^{\text {nd }}$ season as emphasized in Table (9). The application of Stomp at $1.7 \mathrm{l} / \mathrm{fed}$. gave the best results for geranium growth, in the $1^{\text {st }}$ and the $2^{\text {nd }}$ cut in the second season.

This treatment induced the highest growth in term of plant height, branches No., fresh weight $\mathrm{gm} /$ plant and yield of fresh herb/fed.

The values were $99.3,93.7 \mathrm{~cm}, 10,9.7$, branches/plant, 651, $533 \mathrm{gm} /$ plant, 16.28 and 13.33 ton/fed. for the $1^{\text {st }}$ and the $2^{\text {nd }}$ cut respectively.

As indicated previously in the first season, Roal gave also high response followed the
Stomp treatment with regard the geranium growth and yield. The recorded values were 93.7, $92 \mathrm{~cm}, 9,8.7$ branches/plant, 540, 475 $\mathrm{gm} /$ plant, 13.5 and 11.88 ton/fed. in the $1^{\text {st }}$ and $2^{\text {nd }}$ cut respectively.

The highest annual fresh herb yield was obtained from stomp treatments with values of 18.97 and 29.61 ton/fed in the $1^{\text {st }}$ and the $2^{\text {nd }}$ season respectively.

Also, the control (untreated plants) gave the lowest growth as Table (9).

\subsection{Essential oil of geranium plants}

It is noticed that, geranium essential oil production was enhanced by weed control treatments. This enhancement holds true in the two seasons. Stomp application was found to be the effective treatment in this respect. So, the values of essential oil content, yield ( $\mathrm{ml} / \mathrm{plant}$ ) and yield oil $1 /$ fed. recorded a significant increase due to Stomp application in comparison with the untreated plants (control).

The recorded values of Stomp treatments in the $1^{\text {st }}$ and the $2^{\text {nd }}$ cut in the first season were $0.18,0.19 \%, 0.73,0.71 \mathrm{ml} /$ plant, 18.25 and $17.75 \mathrm{l} / \mathrm{fed}$.

The results of the first season were confirmed in the second season. Accordingly, Stomp treatments gave the best results in the $1^{\text {st }}$ and the $2^{\text {nd }}$ cut as shown in Table (10).

The highest essential oil content, oil yield $\mathrm{ml} / \mathrm{plant}$ and yield per fed. were recorded in case of Stomp treatments. The values were 0.17, $0.17 \%, 0.97,0.71 \mathrm{ml} / \mathrm{plant}, 24.25$ and 17.75 $1 /$ fed. the least record was obtained in the case of control plants. Also, the highest annual yield per. 
Table (9): Effect of weed control treatments on growth characters and yield of geranium during 2014/2015 and 2015/2016 seasons.

\begin{tabular}{|c|c|c|c|c|c|c|c|c|c|c|}
\hline \multirow{3}{*}{$\begin{array}{c}\text { Characteristics } \\
\text { Weed Control } \\
\text { Treatments rate/fed }\end{array}$} & \multicolumn{10}{|c|}{$2014 / 2015$ season } \\
\hline & \multicolumn{2}{|c|}{ Plant height $(\mathrm{cm})$} & \multicolumn{2}{|c|}{$\begin{array}{c}\text { No. of } \\
\text { branches/plant }\end{array}$} & \multicolumn{3}{|c|}{ Herb fresh yield gm/plant } & \multicolumn{3}{|c|}{$\begin{array}{l}\text { Herbage yield fed. } \\
\text { (ton/fed) }\end{array}$} \\
\hline & $1^{\text {st }}$ cut & $2^{\text {nd }}$ cut & $1^{\text {st }}$ cut & $2^{\text {nd }}$ cut & $1^{\text {st }}$ cut & $2^{\text {nd }}$ cut & Total & $1^{\text {st }}$ cut & $2^{\text {nd }}$ cut & Total \\
\hline Roal at $750 \mathrm{~cm}^{3}$ & $97.7 b$ & $73.7 b$ & $10.7 \mathrm{ab}$ & $13.7 \mathrm{ab}$ & $288.3 b$ & $265.6 b$ & $553.9 \mathrm{~b}$ & $7.21 \mathrm{~b}$ & $6.64 b$ & $13.85 b$ \\
\hline $\begin{array}{l}\text { Select super at } 500 \\
\mathrm{~cm}^{3}\end{array}$ & $75.7 \mathrm{~d}$ & $61.7 \mathrm{~d}$ & $4.7 \mathrm{c}$ & $11.0 \mathrm{~d}$ & $190.7 \mathrm{e}$ & $167.7 \mathrm{e}$ & $358.3 \mathrm{e}$ & $4.77 \mathrm{e}$ & $4.19 \mathrm{e}$ & $8.96 \mathrm{e}$ \\
\hline Stomp at 1.71 & $105.0 \mathrm{a}$ & $79.7 \mathrm{a}$ & $12.0 \mathrm{a}$ & $14.3 \mathrm{a}$ & $393.7 \mathrm{a}$ & $365.0 \mathrm{a}$ & $758.7 \mathrm{a}$ & $9.85 \mathrm{a}$ & $9.12 \mathrm{a}$ & $18.97 \mathrm{a}$ \\
\hline Black plastic sheet & $79.0 \mathrm{c}$ & $69.3 \mathrm{c}$ & $9.0 \mathrm{~b}$ & $13.0 \mathrm{~b}$ & $265.3 \mathrm{c}$ & $246.0 \mathrm{c}$ & $511.3 \mathrm{c}$ & $6.63 c$ & $6.15 \mathrm{c}$ & $12.78 \mathrm{c}$ \\
\hline Hoeing three times & $77.3 \mathrm{~cd}$ & $62.3 \mathrm{~d}$ & $5.3 \mathrm{c}$ & $12.0 \mathrm{c}$ & $225.3 d$ & $196.3 d$ & $421.6 \mathrm{~d}$ & $5.63 d$ & $4.91 \mathrm{~d}$ & $10.54 d$ \\
\hline \multirow[t]{2}{*}{ Control } & $75.3 \mathrm{~d}$ & $60.0 \mathrm{e}$ & $8.0 \mathrm{c}$ & $9.3 \mathrm{e}$ & $150.0 \mathrm{f}$ & $139.3 \mathrm{f}$ & $289.3 f$ & $3.75 \mathrm{f}$ & $3.48 \mathrm{f}$ & $7.23 \mathrm{f}$ \\
\hline & \multicolumn{10}{|c|}{ 2015/2016 season } \\
\hline Roal at $750 \mathrm{~cm}^{3}$ & $93.7 b$ & $92.0 \mathrm{ab}$ & $9.0 \mathrm{~b}$ & $8.7 b$ & $540.0 \mathrm{~b}$ & $475.0 \mathrm{~b}$ & $1015.0 \mathrm{~b}$ & $13.5 b$ & $11.88 \mathrm{~b}$ & $25.38 b$ \\
\hline $\begin{array}{l}\text { Select super at } 500 \\
\mathrm{~cm}^{3}\end{array}$ & $87.3 \mathrm{c}$ & $83.0 \mathrm{c}$ & $7.3 \mathrm{c}$ & $3.7 \mathrm{~d}$ & $246.3 \mathrm{e}$ & $197.3 \mathrm{e}$ & $443.6 \mathrm{e}$ & $6.16 \mathrm{e}$ & $4.93 \mathrm{e}$ & $11.09 \mathrm{e}$ \\
\hline Stomp at 1.71 & $99.3 \mathrm{a}$ & $93.7 \mathrm{a}$ & $10.0 \mathrm{a}$ & $9.7 \mathrm{a}$ & $651.0 \mathrm{a}$ & $533.3 \mathrm{a}$ & $1184.3 \mathrm{a}$ & $16.28 \mathrm{a}$ & $13.33 \mathrm{a}$ & $29.61 \mathrm{a}$ \\
\hline Black plastic sheet & $91.3 b$ & $90.3 b$ & $9.0 \mathrm{~b}$ & $8.3 b$ & $443.0 \mathrm{c}$ & $397.0 \mathrm{c}$ & $840.0 \mathrm{c}$ & $11.08 \mathrm{c}$ & $9.93 \mathrm{c}$ & $21.01 \mathrm{c}$ \\
\hline Hoeing three times & $88.3 \mathrm{c}$ & $84.3 \mathrm{c}$ & $8.3 b$ & $7.0 \mathrm{c}$ & $392.3 d$ & $323.0 \mathrm{~d}$ & $715.3 d$ & $9.81 \mathrm{~d}$ & $8.08 \mathrm{~d}$ & $17.89 \mathrm{~d}$ \\
\hline Control & $55.0 \mathrm{~d}$ & $54.7 \mathrm{~d}$ & $4.7 \mathrm{~d}$ & $2.3 \mathrm{e}$ & 158.0f & $142.0 \mathrm{f}$ & $300.0 \mathrm{f}$ & $3.95 f$ & $3.55 \mathrm{f}$ & $7.5 \mathrm{f}$ \\
\hline
\end{tabular}

Table (10): Effect of weed control treatments on essential oil of geranium during 2014 and 2015 seasons.

\begin{tabular}{|c|c|c|c|c|c|c|c|c|}
\hline \multirow{3}{*}{$\begin{array}{c}\text { Characteristics } \\
\text { Weed Control Treatments } \\
\text { rate/fed }\end{array}$} & \multicolumn{8}{|c|}{ season $2014 / 2015$} \\
\hline & \multicolumn{2}{|c|}{ Volatile oil \% } & \multicolumn{3}{|c|}{ Volatile oil yield (ml/plant) } & \multicolumn{3}{|c|}{ yield oil (l/fed) } \\
\hline & $1^{\text {st }}$ cut & $2^{\text {nd }}$ cut & $1^{\text {st }}$ cut & $\begin{array}{l}2^{\text {nd }} \\
\text { cut }\end{array}$ & Total & $1^{\text {st }}$ cut & $2^{\text {nd }}$ cut & Total \\
\hline Roal at $750 \mathrm{~cm}^{3}$ & $0.17 \mathrm{ab}$ & $0.23 \mathrm{ab}$ & $0.49 a$ & $0.61 \mathrm{~b}$ & $1.07 \mathrm{~b}$ & $15.00 \mathrm{~b}$ & $12.00 \mathrm{~b}$ & $27.00 \mathrm{~b}$ \\
\hline Select super at $500 \mathrm{~cm}^{3}$ & $0.15 b$ & $0.17 \mathrm{~d}$ & $0.29 b c$ & $0.3 \mathrm{c}$ & $0.59 \mathrm{~d}$ & $7.25 c$ & $7.50 \mathrm{c}$ & $14.75 \mathrm{c}$ \\
\hline Stomp at 1.71 & $0.18 \mathrm{a}$ & $0.19 \mathrm{c}$ & $0.73 \mathrm{a}$ & $0.71 \mathrm{a}$ & $1.44 \mathrm{a}$ & $18.25 \mathrm{a}$ & $17.75 \mathrm{a}$ & $36.00 \mathrm{a}$ \\
\hline Black plastic sheet & $0.17 \mathrm{a}$ & $0.23 \mathrm{ab}$ & $0.57 \mathrm{a}$ & $0.46 b$ & $1.03 b c$ & $14.25 b$ & $11.50 \mathrm{~b}$ & $25.75 b$ \\
\hline Hoeing three times & $0.15 b$ & $0.27 \mathrm{a}$ & $0.52 \mathrm{ab}$ & $0.35 \mathrm{c}$ & $0.87 \mathrm{c}$ & $13.08 \mathrm{~b}$ & $8.75 d$ & $21.75 b$ \\
\hline Control & $0.13 c$ & $0.13 \mathrm{e}$ & $0.18 \mathrm{c}$ & $0.2 \mathrm{~d}$ & $0.38 \mathrm{e}$ & $4.5 \mathrm{c}$ & $5.00 \mathrm{e}$ & $9.5 \mathrm{~d}$ \\
\hline & \multicolumn{8}{|c|}{ season $2015 / 2016$} \\
\hline Roal at $750 \mathrm{~cm}^{3}$ & $0.17 \mathrm{a}$ & $0.17 \mathrm{ab}$ & $0.93 \mathrm{a}$ & $0.81 \mathrm{a}$ & $1.74 \mathrm{a}$ & $23.25 \mathrm{a}$ & $20.25 a$ & $43.5 \mathrm{a}$ \\
\hline Select super at $500 \mathrm{~cm}^{3}$ & $0.15 \mathrm{a}$ & $0.13 \mathrm{c}$ & $0.37 \mathrm{c}$ & $0.26 \mathrm{c}$ & $0.63 c$ & $9.25 \mathrm{c}$ & $6.5 \mathrm{c}$ & $15.75 \mathrm{c}$ \\
\hline Stomp at 1.71 & $0.17 \mathrm{a}$ & $0.17 \mathrm{ab}$ & $0.97 \mathrm{a}$ & $0.71 \mathrm{a}$ & $1.68 \mathrm{a}$ & $24.25 \mathrm{a}$ & $17.75 \mathrm{a}$ & $42.00 \mathrm{a}$ \\
\hline Black plastic sheet & $0.15 a$ & $0.15 b$ & $0.67 b$ & $0.61 b$ & $1.28 \mathrm{~b}$ & $16.75 b$ & $15.25 b$ & $32.00 \mathrm{~b}$ \\
\hline Hoeing three times & $0.17 \mathrm{a}$ & $0.17 \mathrm{a}$ & $0.67 b$ & $0.56 b$ & $1.23 \mathrm{~b}$ & $16.75 b$ & $14.00 \mathrm{~b}$ & $30.75 b$ \\
\hline Control & $0.15 \mathrm{a}$ & $0.13 c$ & $0.2 \mathrm{~d}$ & $0.15 \mathrm{~d}$ & $0.35 \mathrm{~d}$ & $5.00 \mathrm{c}$ & $3.75 \mathrm{~d}$ & $8.75 \mathrm{~d}$ \\
\hline
\end{tabular}


Table (11): Chemical composition of geranium oil as affected by weed control treatments.

\begin{tabular}{|c|c|c|c|c|c|c|c|c|c|}
\hline $\begin{array}{c}\text { Weed Control } \\
\text { Treatments rate/fed }\end{array}$ & 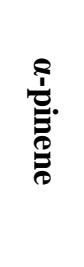 & 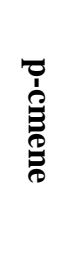 & 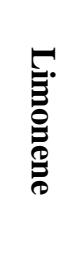 & 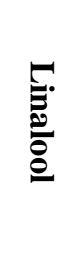 & 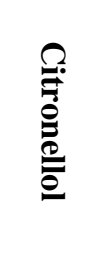 & 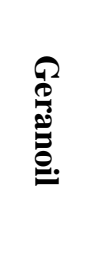 & 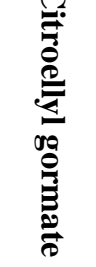 & 四 & 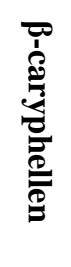 \\
\hline Roal at $750 \mathrm{~cm}^{3}$ & 3.36 & 3.05 & 5.74 & 6.3 & 21.89 & 38.27 & 10.66 & 2.38 & 1.48 \\
\hline Select super at $500 \mathrm{~cm}^{3}$ & 3.42 & 4.4 & 5.26 & 7.47 & 21.23 & 34.6 & 10.09 & 2.75 & 2.66 \\
\hline Stomp at 1.71 & 3.47 & 3.11 & 5.8 & 6.08 & 22.95 & 35.92 & 10.92 & 2.66 & 2.15 \\
\hline Black plastic sheet & 3.87 & 3.2 & 6.15 & 6.58 & 23.48 & 34.19 & 10.58 & 2.43 & 1.72 \\
\hline Hoeing three times & - & 4.32 & 3.97 & 5.66 & 23.51 & 35.08 & 10.46 & 2.56 & 1.79 \\
\hline Control & 2.39 & 2.51 & 5.76 & 5.98 & 22.19 & 35.2 & 11.38 & 3.08 & 2.46 \\
\hline
\end{tabular}

fed. was $36.01 /$ fed in the $1^{\text {st }}$ season and $421 / f e d$. in the $2^{\text {nd }}$ one, Table (10). However, Roal gave the highest oil yield in the $2^{\text {nd }}$ season only 43.5 $1 /$ fed.

\subsubsection{Chemical composition of geranium essential oil}

Volatile oil samples were taken from the oil obtained in the second cut of the second season and analyzed using gas liquid chromatography (GLC), to determine the oil components i.e. $\alpha$ Pinene, $\quad \beta$-Pinene, Limonene, Linalool, Citronellol, Geraniol, Citroellyl formate, Eugenol and $\beta$-caryophyllene, as shown in Table (11) and Figs (15-20). Geraniol was the main component of geranium essential oil. The obtained results showed that the application of Roal at $750 \mathrm{~cm}^{3} / \mathrm{fed}$. gave the highest percentage of geraniol $(38.27 \%)$. On the other hand, the lowest percentage of geraniol (34.19\%) was using the black plastic sheet.

As citronellol was the second main component, hand hoeing three times $(23.51 \%)$ gave the highest percentage. While the lowest percentage of citronellol $(21.23 \%)$ was obtained in the case of Select super at $500 \mathrm{~cm}^{3} / \mathrm{fed}$.

\subsection{Residues analysis}

The stability of the three herbicides under the current study were applied pre-emergence (Pendimethalin and Oxyfluorfen) and postemergence at 30 days after planting (DAP) (Clethodim). These herbicides (Butralin, Pendimethalin Oxyfluorfen and Clethodim) degraded into the spearmint plants and the GLC could not read any values.
The results in Table (12) and Figs (21-26) exhibit the residue analyses of Pendimethalin Oxyfluorfen and Clethodim herbicides. The residues level of Pendimethalin Oxyfluorfen and Clethodim herbicides in geranium plants in all the treatments were lower than maximum residue levels (MRL) which were 0.05, 0.3 and ppm, respectively. The results are in the agreement obtained by European Food Safety Authority (EFSA), (2012).

Table(12): Calibration of Pendimenthalin, Oxyfluorfen amd Clethodim geranium.

\begin{tabular}{|c|c|c|}
\hline $\begin{array}{c}\text { Herbicides } \\
\text { name }\end{array}$ & $\begin{array}{c}\text { Residual } \\
\text { (ppm) }\end{array}$ & $\begin{array}{c}\text { Max. Residual } \\
\text { Levels [mg/kg] }\end{array}$ \\
\hline Pendimethalin & N D & 0.05 \\
Oxyfluorfen & N D & 0.3 \\
Clethodim & N D & 0.02 \\
\hline
\end{tabular}

\subsection{Determination of economics for weed} control in the geranium plants.

The total cost of the weeded check was 11.96 and 12.46 LE in 2014 and 2015 seasons, respectively, considered the fixed cost (land preparation, transplantation fertilization irrigation, insect control, harvesting and transportation) in addition; to the cost of the treatments on the others as shown (Table 13).

In both seasons, Stomp at $1.7 \mathrm{l} / \mathrm{fed}$. gave the highest values of gross income net benefits and the percentage of benefit/cost by $46.8 \& 34.64$ 

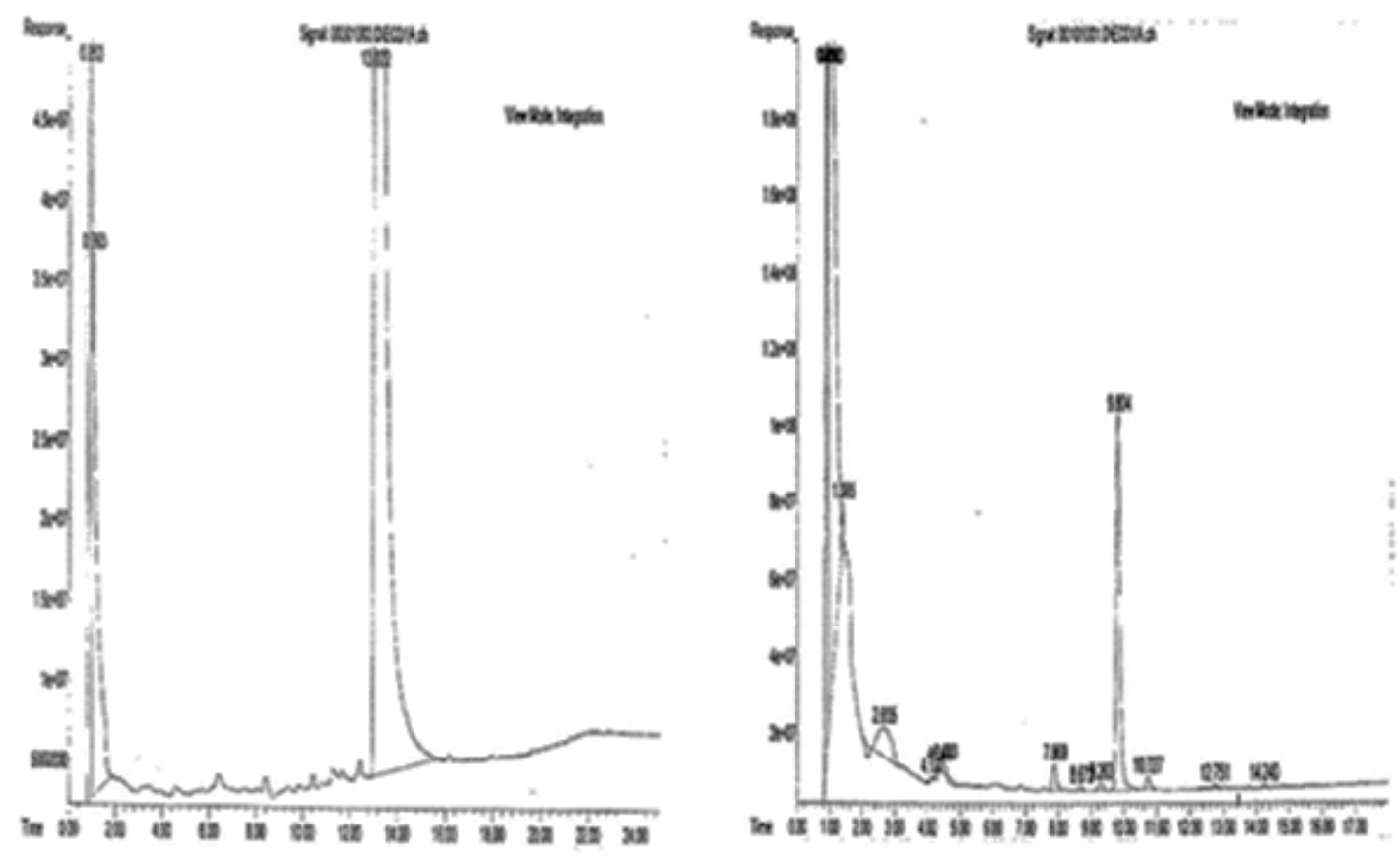

Fig (11): Standard of Goal

Fig (12): Residual of Goal in spearmint
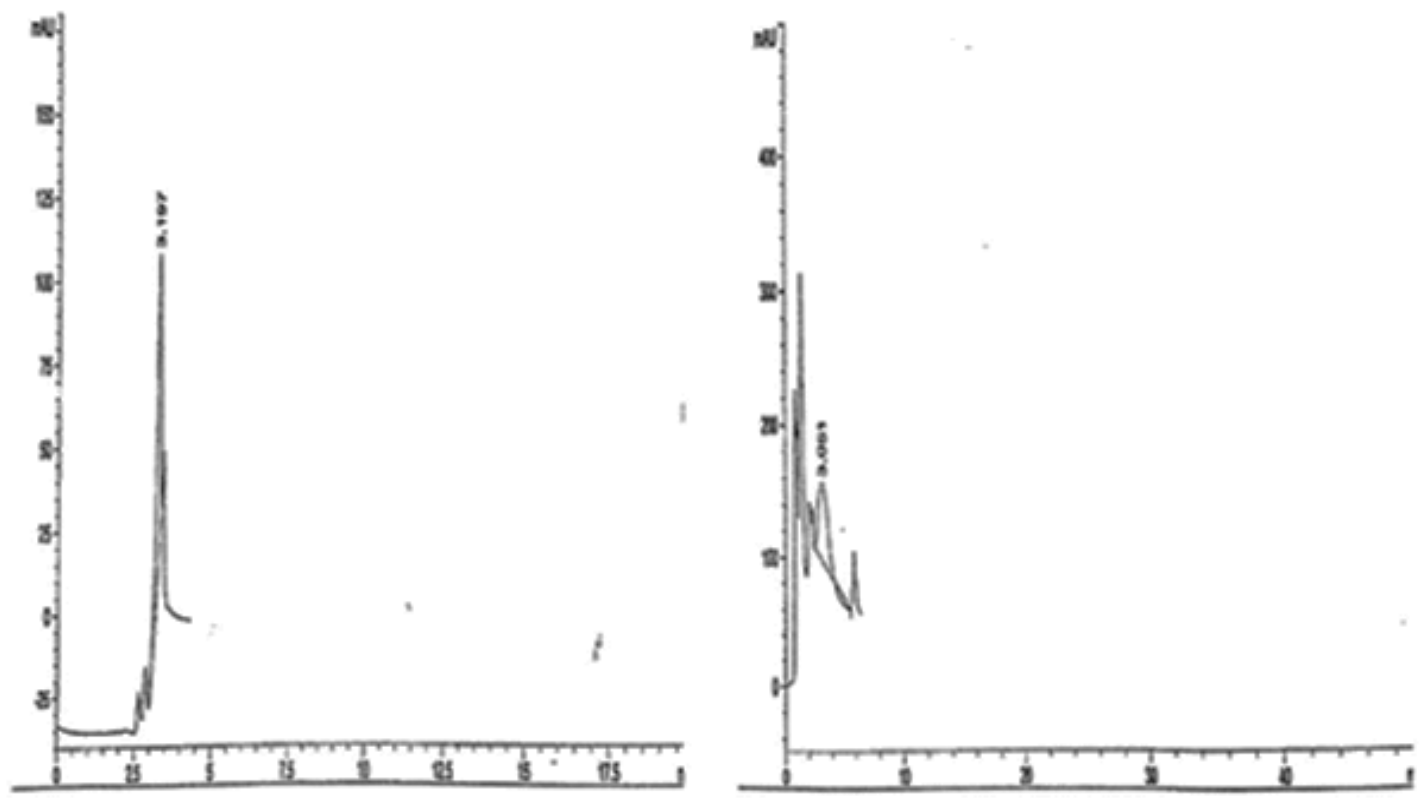

Fig (13): Standard of select super.

Fig (14) : Residual of select super in spearmint 


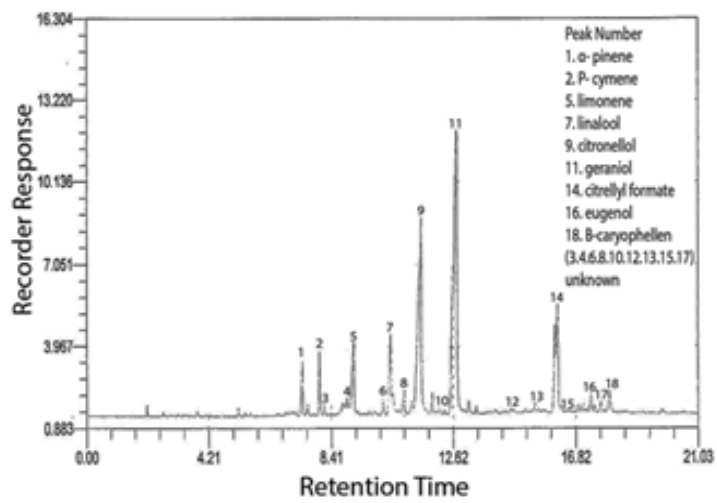

Fig (15): Chromatogram of Geranium essential oil (control)

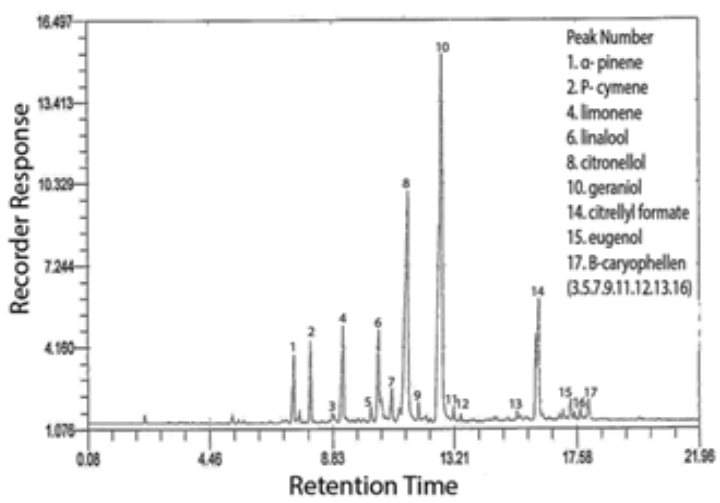

Fig (17): Chromatogram of Geranium essential oil (black plastic sheet)

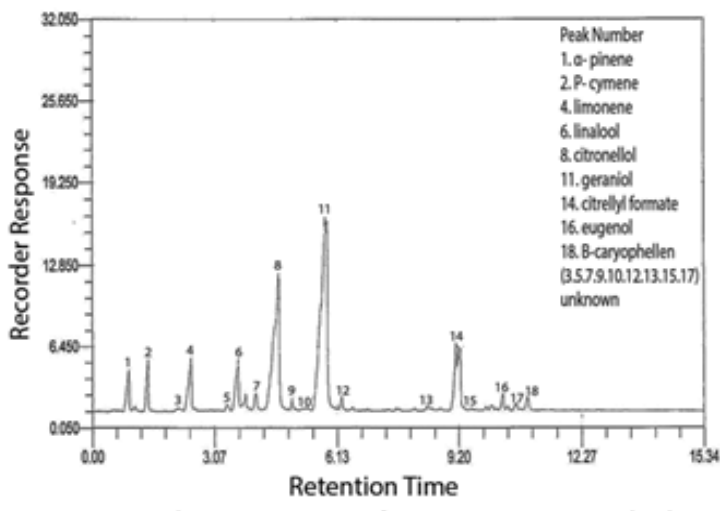

Fig (19): Chromatogram of Geranium essential oil (Roal at $750 \mathrm{~cm}^{3}$ )

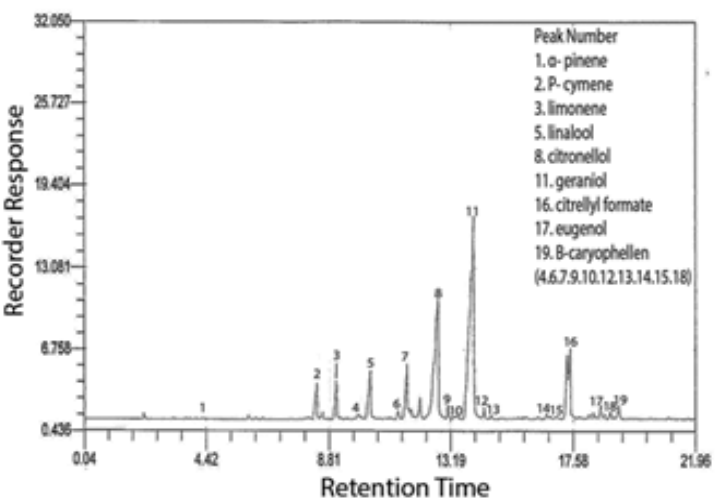

Fig (16): Chromatogram of Geranium essential oil (heoing three time)

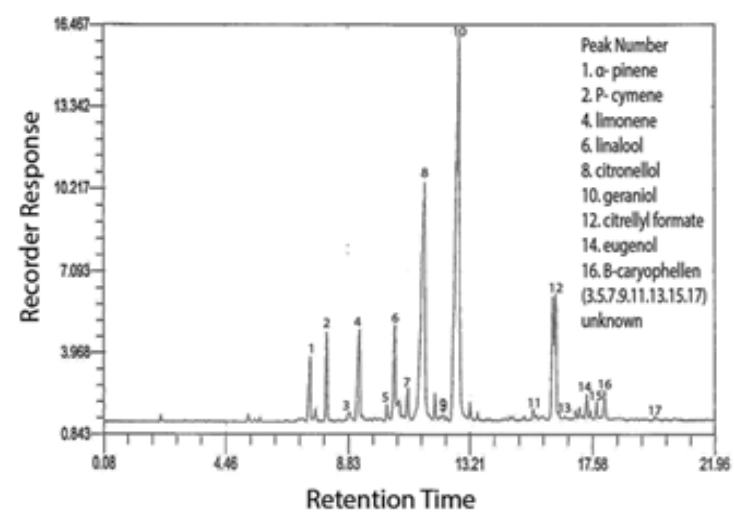

Fig (18): Chromatogram of Geranium essential oil (stomp at $1.7 \mathrm{l} / \mathrm{fed}$ )

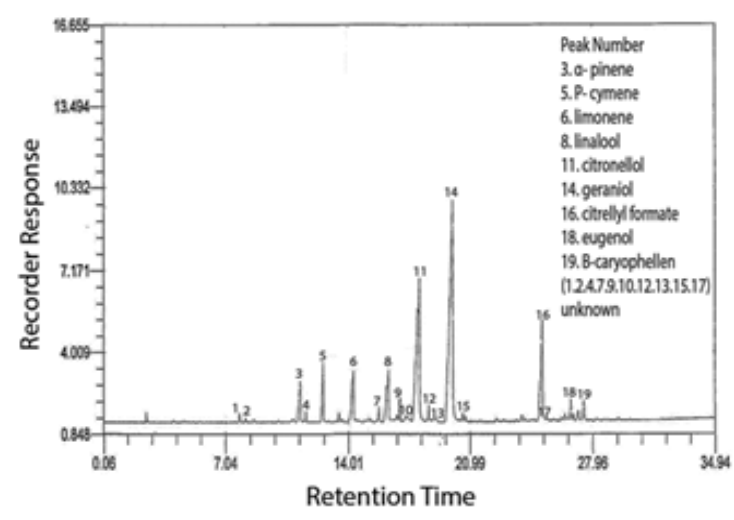

Fig (20): Chromatogram of Geranium essential oil (select at $500 \mathrm{~cm}^{3}$ ) 


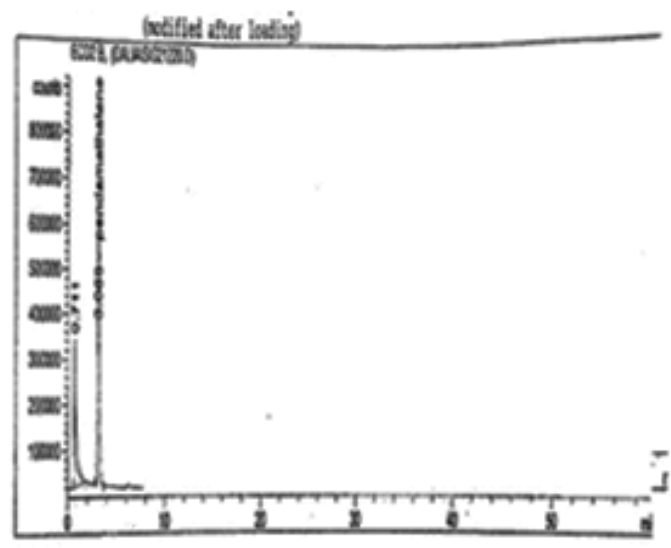

Fig (21): Standard of Stomp extra

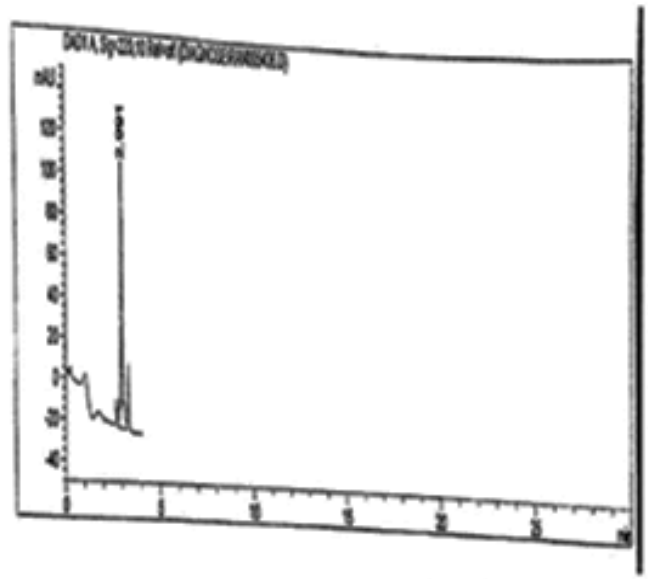

Fig (23): Standard of Clethodim

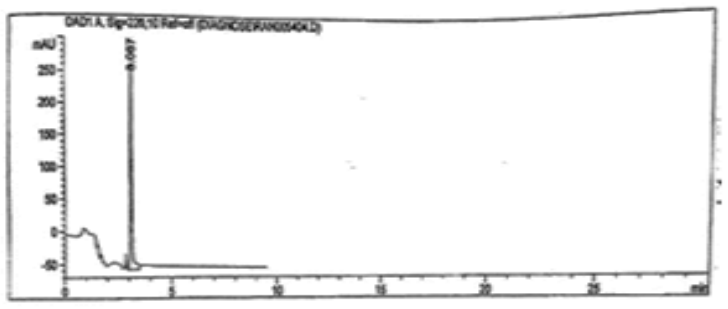

Fig (25): Standard of Oxyfluorfen

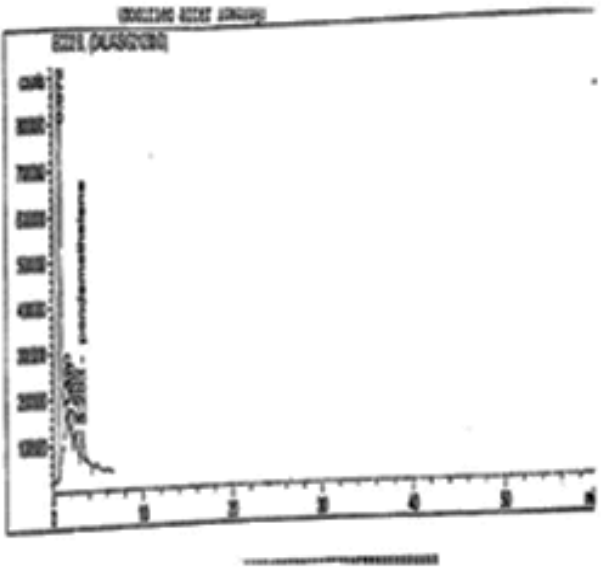

Fig (22): Residual of Stomp extra in geranium.

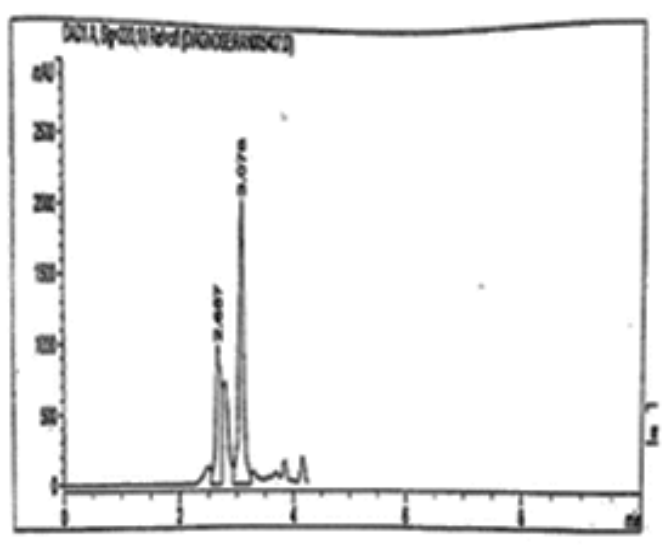

Fig (24): Residua of Clethodim in geranium

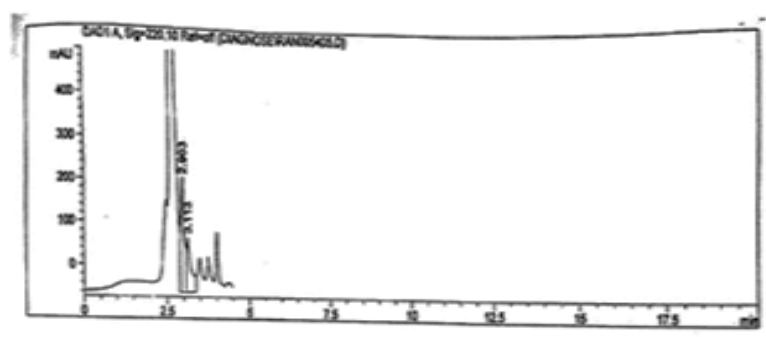

Fig (26): Residual of Oxyfluorfen in geranium. 
Table (13): Determination of economics for weed control in geranium plants.

\begin{tabular}{|c|c|c|c|c|c|c|c|c|}
\hline Seasons & \multicolumn{4}{|c|}{ 2014-2015 season } & \multicolumn{4}{|c|}{ 2015-2016 seasion } \\
\hline $\begin{array}{c}\text { Weed control } \\
\text { Treatments } \\
\text { Rate/fed }\end{array}$ & $\begin{array}{c}\text { Total } \\
\text { cost Ths. } \\
\text { L.E. }\end{array}$ & $\begin{array}{c}\text { Gross } \\
\text { income } \\
\text { Ths } \\
\text { L.E. }\end{array}$ & $\begin{array}{c}\text { Net } \\
\text { Benefit } \\
\text { Ths } \\
\text { L.E. }\end{array}$ & $\mathrm{B} / \mathrm{C}$ & $\begin{array}{l}\text { Total } \\
\text { cost } \\
\text { Ths. } \\
\text { L.E. }\end{array}$ & $\begin{array}{c}\text { Gross } \\
\text { income } \\
\text { Ths } \\
\text { L.E. }\end{array}$ & $\begin{array}{c}\text { Net } \\
\text { Benefit } \\
\text { Ths L.E. }\end{array}$ & $\mathrm{B} / \mathrm{C}$ \\
\hline Roal at $750 \mathrm{~cm}^{3}$ & 12.06 & 35.1 & 33.04 & 2.91 & 12.56 & 65.25 & 52.69 & 5.19 \\
\hline $\begin{array}{l}\text { Select super at } \\
500 \mathrm{~cm}^{3}\end{array}$ & 12.09 & 19.18 & 7.09 & 1.59 & 12.59 & 20.48 & 7.89 & 1.36 \\
\hline Stomp at $1.7 \mathrm{I}$ & 12.16 & 46.8 & 34.64 & 3.85 & 12.61 & 54.6 & 41.99 & 4.33 \\
\hline $\begin{array}{l}\text { Black plastic } \\
\text { sheet }\end{array}$ & 13.47 & 33.48 & 20.01 & 2.49 & 13.96 & 41.6 & 27.64 & 2.98 \\
\hline $\begin{array}{l}\text { Hoeing three } \\
\text { times }\end{array}$ & 12.56 & 28.28 & 15.72 & 2.25 & 13.36 & 39.98 & 26.62 & 2.991 \\
\hline Control & 11.96 & 12.35 & 0.39 & 1.03 & 12.46 & 13.0 & 0.54 & 1.04 \\
\hline
\end{tabular}

thS LE and $3.85 \%$ and $54.6 \& 41.99$ thS LE and $4.33 \%$, respectively, in the first and the second seasons. Roal at $750 \mathrm{~cm}^{3} / \mathrm{fed}$. was the following treatment which increased the respective previous economic values by $35.1 \& 33.04$ Ths. LE and $2.91 \%$ and $65.25 \& 52.69$ Ths. LE and $5.19 \%$., respectively, in both seasons. Whilst, the rest treatments i.e Black plastic sheet., hand hoeing three times and Select super at 500 $\mathrm{cm}^{3} /$ fed. were still superior of the previous economic value compared to the unweeded check (Table 13).

\section{Conclusion}

It could be recommended to treat spearmint and geranium with Stomp at $1.7 \mathrm{l} / \mathrm{fed}$. because it was the best control treatment, as the vegetative growth, herb yield and essential oil production increased while the broad leave and grassy weeds showed inhibition effect due to this treatment. Also, mulching with black plastic sheets could be as a good substitutes for weed control instead of the herbicides and can be recommended for controlling annual weeds especially in organic agriculture.

\section{REFERENCES}

Anonymous (2012). Advanced Course "Medical from plants" Meditrreanean Agronomic Institue of Zaragoza Spain,16-21 jan.,2012

Bernsier J.P. and Gallotte P. (1989). Chemical weed control in peppermint post-planting. Herb Galica 1:33-37.

British Pharmacopoeia (1963). Determination of volatile oil in drug. The pharma Guetical Press London, UK.
Bunzen J.N, Guchard J. Labbe O. Sperinnet P.J. and Trenchant J. (1969). Practical manual of GAS chromatography. J. (Ed) Trechant Ed., El-Seiver Publ. Comp., Amesterdam, London, U.K.

Egyptian Ministry of Agriculture (2015). Bulletin of Agriculture Statisitcs -part (1)winter crops, 2015.

El-Masry M.H., Zaied A.A. and El-Deeb S. (1989). Effect of certain herbicides on weed control, quality and quantity of geranium grown at south Al-Tahrir. Minufia J. Agric. Res. 14:(20): 935-944.

European Food Safety Authority (EFSA) Parma Italy (2012). Reasoned opinion on the review of the exsiting maximum residue levels (MRLs) for pendimethalin according to Article 12 of Regulation (EC) No 396/2005. EFSA. 10 (4): 2683.

Gomez K.A. and Gomez A.A. (1984). Statistical Procedure for Agriculture Research .John Wiley \& Sons, Inc. New York, USA.

Guenther E. (1961). The essential oils. Vol. IV. $4^{\text {th }}$ Ed.p20-63.D, van Nostrand Company, Lnc., New york, U.S.A.

Heady E. O. and Dillon J.L.(1961). Agriculture production functions. Library of congress catalog card number: 60-11128, lowa State University Press, U.S.A.

Hoftman E. (1967). Chromatography. Reinhold Pub. Corp., $2^{\text {nd }}$ Ed.pp.208-515.

Jackson M.L.(1967). Soil Chemical Analysis. Prentic-Hall. of India Private Limited, New Delhi. India.

Katoch P. C., Bhardwaj S.D. Kaushal A.N and Gupta R. (1982). Effect on herbage yield and oil content by different methods of 
weed control in Mentha pipertia Linn.Indian J. agric.Res., 16(3):169-172.

Kothari S.K., Singh C.P. and Singh K. (2002). Weed control in rose-scented geranium (Pelargonium spp). Pest Manag.Sci. 58(12): 1254-1258.

Mineta T., Hidaka K., Enomoto T. and Oki, Y.(1997). Changes in weed communities in direct-seeded paddy fields under Astragalus sinicus L. livig mulch and notillage cultivation during three years. [Japanese]. Weed Sci. Tech. 42(2):88-96.

Muni R. R. and Roy D. S.K.(2003). Influence of an organic mulching on fertilizer nitrogen use efficiency, and herb and essential oil yields in geranium (Pelargonium graveolens). Biores. Tech. 87(3):273278.23.

Nguyen T.D., Han E.M., Seo M.S., Kim S.R. Yun M.Y., Lee D.M. and Lee, G.H. (2008). A multi-residue method for the determination of 204 pesticides in rice paddies using gas chromatography/mass spectrometry. Analy. Chem. Acta, 619: 67-74.
Piper C.S. (1950). Soil and plant Analysis. Int. Sci. Publ. INC., New York, U.S.A.

Rankova Z. and Koumanov K. (2004). Efficiency on some soil herbicides in a rasberry plantation under drip irrigation. Jugoslovensko Vacarstvo, 38(3/4): 163169.

Romanowski R., Liedle R., Lindsay B., Persing T., Ross T.E. E.A. Green R. and Reed G. (1980) Results of field experiments on weed control in vegetable crops. Horticulture Crops Pesticide Studies Results, Departments of Entomology, Horticulture and Botany and Plant Pathology, Purdue University. (CES Paper 78) PP: 5-46.

Topps J.H. and Wain R.L. (1957). Investigation of fungitoxicity of 3 and 5-alkyl saliclanilids and Parachloro aniline. Ann. Appli. Biol., 45 (3): 506-511.

Wallia U.S. Sandhu K.S. Sainai S.S. and Samra J.S. (1980). Studies on chemical weed control in Japanese mint. (Mentha arvensis L.). India J. weed Sci., 13(2): 181-185. 


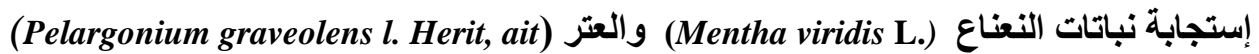
لعمليات مكافحة الحثائش المختلفة أشرف محمد فضل الله ـ سعاد محمد محمود سالم* ـإبرا هيم السيد سليمان المعمل المركزي لبحوث الحشائش و* معهد بحوث البساتين - مركز البحوث الزراعية ـ الجيزة. مصر.

\section{ملخص}

أقيمت أربع تجارب حقلية بمزرعة النباتات الطبية والعطرية بالقناطر الخيرية بمحافظة القليوبية ــ معهد بحوث

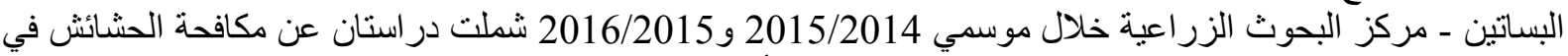

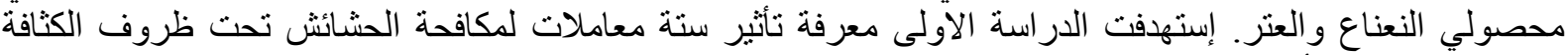

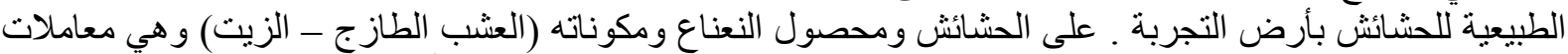

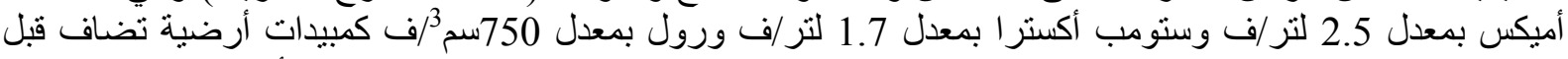

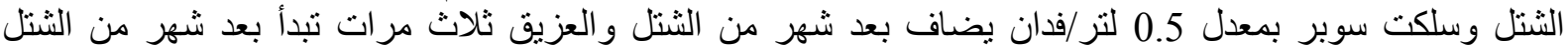

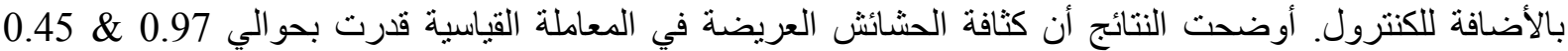
طن/فدان بينما كثافة الحشائش الحولية الضيقة كانت 0.43 \& 0.24 طن/فدان في في موسمي 2014 و 2015 ، على على التو الي

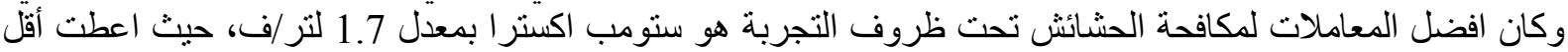

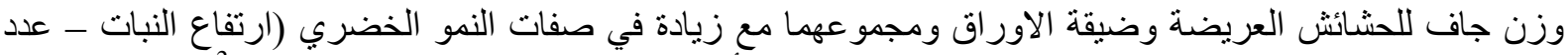

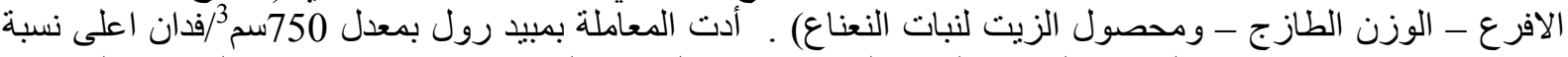

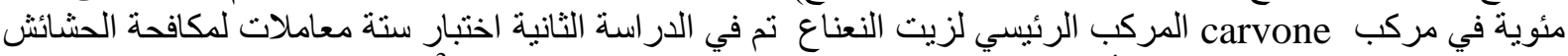

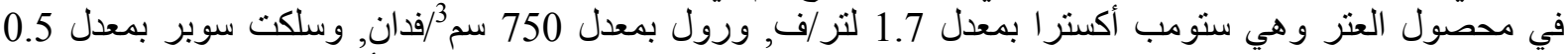

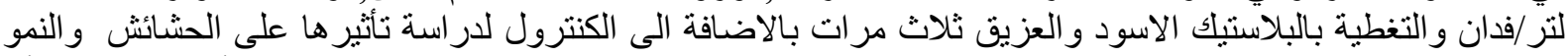

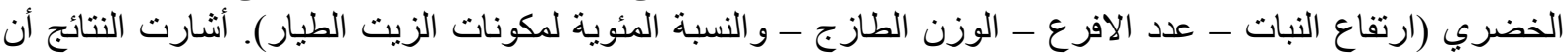

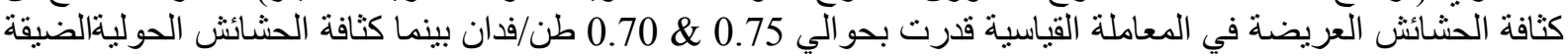

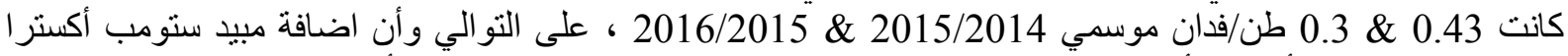

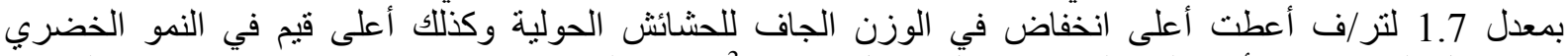

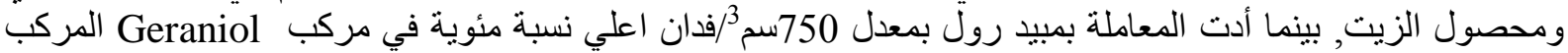

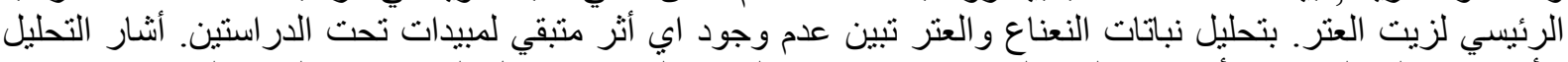

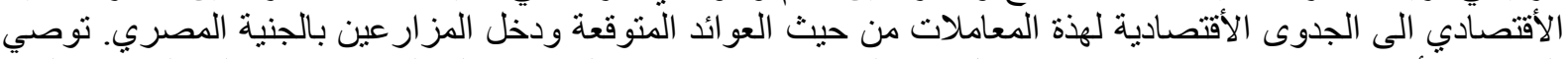

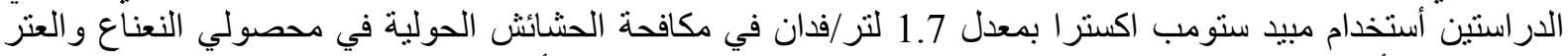

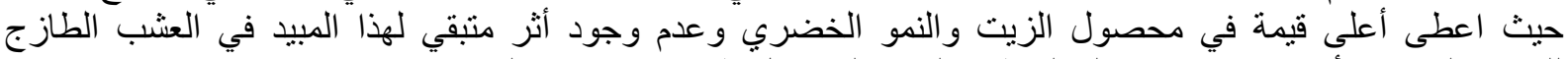

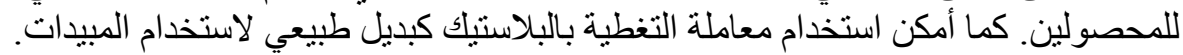

